\title{
Review of The Fund's Income Position for FY 2021 and FY 2022
}




\section{INTERNATIONAL MONETARY FUND}

\section{IMF POLICY PAPER}

\section{REVIEW OF THE FUND'S INCOME POSITION FOR FY 2021 AND FY 2022}

IMF staff regularly produces papers proposing new IMF policies, exploring options for reform, or reviewing existing IMF policies and operations. The following documents have been released and are included in this package:

- A Press Release.

- The Staff Report on the Review of the Fund's Income Position for FY 2021 and FY 2022 was prepared by IMF staff and completed on April 12, 2021 for the Executive Board's consideration on April 27, 2021.

The IMF's transparency policy allows for the deletion of market-sensitive information and premature disclosure of the authorities' policy intentions in published staff reports and other documents.

Electronic copies of IMF Policy Papers

are available to the public from

http://www.imf.org/external/pp/ppindex.aspx

\section{International Monetary Fund Washington, D.C.}




\section{IMF Executive Board \\ Reviews the Fund's Income Position for FY 2021 \\ and FY 2022}

FOR IMMEDIATE RELEASE

- Net operational income, mainly comprising income from lending and investments, anticipated to remain strong for FY 2021 reflecting the ongoing elevated use of Fund credit resulting from the unprecedented support to the membership in the wake of the pandemic. This trend is expected to continue in FY 2022.

- A projected unrealized pension-related accounting gain is expected to increase overall Fund income in FY 2021 reversing a large portion of the corresponding loss experienced last year.

Washington, DC - [May 28, 2021]: On April 27, 2021 the Executive Board of the International Monetary Fund (IMF) completed its annual review of the Fund's income position for the financial year (FY) ending April 30, 2021.

\section{FY 2021 Income Position}

Net operational income, of about SDR 1 billion (US $\$ 1.4$ billion), mainly comprising income from lending and investments, is anticipated to remain strong for FY 2021, even though lower than the April 2020 estimate. Robust expected income from lending reflects the ongoing elevated use of Fund credit. The actuarial remeasurement of staff retirement plan assets and liabilities is projected to make a substantial but unrealized contribution of about SDR 2.5 billion (US $\$ 3.5$ billion) to the net income for the year. ${ }^{1}$ The net income will increase the Fund's precautionary balances, which are projected to rise to SDR 19.5 billion (US $\$ 28$ billion) at end-FY 2021 from SDR 16.0 billion at end-FY 2020.

The Executive Board also adopted several other decisions that have a bearing on the Fund's finances. These included decisions to transfer income from the Fixed-Income Subaccount of the Fund's Investment Account (IA) to the General Resources Account (GRA); to place a portion of FY 2021 General Resources Account net income equivalent to the GRA's net loss in FY 2020 to the Fund's Special Reserve, and to place any additional net income in equal parts to the Fund's Special Reserve and the General Reserve; to transfer currencies equivalent to the increase in the Fund's reserves from the GRA, after taking into account the transfer of income from the Fixed-Income Subaccount for use in meeting FY 2021 administrative expenses, to the Investment Account.

The Executive Board also took decisions to reimburse costs to the GRA for the expenses of conducting the business of the SDR department; to suspend the reimbursement to the GRA

${ }^{1}$ IAS 19 'Employee Benefits', requires the actuarial remeasurement of post-employment obligations. 
for Poverty Reduction and Growth Trust administrative expenses for FY 2021; and to retain the income of the Endowment Subaccount for FY 2021.

Projections of the Fund's income remain subject to larger than normal uncertainties one year into the COVID-19 pandemic. Changes in key assumptions such as the discount rate used to measure the Fund's retirement plan obligations and asset returns can have a large impact on the actual outcome. The FY 2021 annual financial statements will update for the impact of changes in key assumptions made at the time of the April projections.

\section{FY 2022 Income Position and Lending Rate}

As noted above, operational income for FY 2022 is expected to remain strong, with projections pointing to annual net income of SDR 2.2 billion (US $\$ 3.2$ billion). However, these projections are subject to a high degree of uncertainty related to the scale of new lending associated with the COVID-19 economic fallout and the path of any recovery; as well as the timing and amounts of disbursements under approved arrangements included in the projections. One year into the COVID-19 pandemic, uncertainties surrounding the prospects for recovery remain and are likely to impact actuarial assumptions such as the discount rate, and the performance of the Fund's investment and retirement plan asset portfolios. Positive projected net income should allow the Fund to continue to accumulate precautionary balances.

The Fund charges member countries a basic rate of charge on the use of Fund credit, which is determined as the SDR interest rate plus a margin expressed in basis points. In April 2020 the Executive Board set the margin for this rate of charge at 100 basis points for financial years FY 2021 and FY 2022. In the context of this year's comprehensive review of the Fund's income position at the midpoint of this two-year period, the Executive Board concluded that the margin should remain unchanged. 


\section{INTERNATIONAL MONETARY FUND}

April 12, 2021

\section{REVIEW OF THE FUND'S INCOME POSITION FOR FY 2021} AND FY 2022

\section{EXECUTIVE SUMMARY}

This paper updates the projections of the Fund's income position for FY 2021 and FY 2022 and proposes decisions for the current and next financial year. The Fund's overall net income for FY 2021 is projected at about SDR 4.1 billion, higher than both the interim estimate of SDR 3.2 billion and the April 2020 estimate.

Projections of the Fund's income are subject to larger than normal uncertainties related to the impact of the COVID-19 pandemic on key assumptions. For FY 2021, these uncertainties relate mainly to the discount rate to be used to measure the Fund's retirement plan obligations at April 30, 2021 and to the full year asset returns on the retirement plan and the Endowment Subaccount (EA). For FY 2022, a key additional uncertainty is the scale of new lending associated with the economic fallout from the COVID-19 pandemic.

The paper proposes that the EA payout be delayed by one year to allow the payout decision to be informed by the outcome of the Investment Account (IA) review, including possible revisions to the investment strategy and the long-term return outlook.

Following the informal meeting with Executive Directors in October 2020 to discuss provisioning for impairment losses, staff proposes that the approach for addressing potential cases of impairment, including the use of provisioning, be formally endorsed in this paper.

As discussed at the April 1 informal session with Executive Directors on the review of concessional financing and policies staff proposes that the temporary access decisions be complemented by a one-year suspension of the reimbursement of PRGT administrative expenses.

The paper recommends that a portion of General Resources Account (GRA) net income for FY 2021 equivalent to the net loss incurred in FY 2020 be placed to the special reserve consistent with the Fund's recent practice to allow for complete recovery of the erosion of the special reserve. The remainder would be placed equally to the special and general reserve to allow for the buildup of the reserves. After the placement of GRA FY 2021 net income to reserves, precautionary balances are projected to reach SDR 19.5 billion at the end of FY 2021. The paper further proposes to transfer to the 
Investment Account currencies equivalent to the increase in the Fund's GRA reserves since the time of the last transfer in FY 2019; after taking into account the transfer of income from the Fixed-Income Subaccount for use in meeting FY 2021 administrative expenses.

In April 2020, the margin for the rate of charge was set at 100 basis points for the two years FY 2021 and FY 2022. The margin may be adjusted before the end of the first year of this two-year period (i.e., FY 2021) but only if warranted by fundamental changes in the underlying factors relevant for the establishment of the margin at the start of the two-year period. Staff does not propose any change in the margin.

The projections for FY 2022 point to a net income position of SDR 2.2 billion, excluding the impact of any pension-related gain or loss. These projections are subject to considerable uncertainty and are sensitive to a number of assumptions. 
Approved By

Andrew Tweedie
Prepared by the Finance Department in consultation with the Legal Department and the Office of Budget and Planning.

\section{CONTENTS}

INTRODUCTION

FY 2022 INCOME OUTLOOK

A. Summary of Key Risks

B. Key FY 2022 Income Outlook Factors

C. Review of the Margin for the Rate of Charge

\section{FIGURES}

1. Summary of Proposed Disposition Decisions

2. Illustrative Examples of FY 2021 GRA Net Income-Sensitivity to Changes in the Discount Rate and Asset Return Assumptions

3. Projected Precautionary Balances Accumulation

4. EMBIG Spreads: Total Composite and Bottom Quartile

5. Projected Non-Lending Operational Income and Non-Lending Expenses

\section{TABLES}

1. Projected Income and Expenditures-FY 2021

2. Reconciliation of Pension-Related (IAS 19) Gains/(Losses)__ 11

3. Projected Income Sources and Uses_FY 2021-2022__

4. Sensitivity Analysis-Effect of Changes in Selected Assumptions on FY 2022 Projected Income

5. Income from the Margin and Reserve Accumulation__

6. Long-Term Credit Market and Comparator Spreads __ $\underline{26}$

7. Recent Burden Sharing Adjustment Rates__ $\underline{28}$

\section{ANNEXES}

I. Decisions in Effect Related to the FY 2021 Income Position __ $\underline{32}$

II. IAS 19 Accounting for Employee Benefits _

III. EA Payout Policy Framework __ $\quad \underline{35}$

IV. Endowment Payout-Practical Considerations__

V. Assumptions Underlying the Income Projections__

VI. Consolidated Medium-Term Income and Expenses__ $\underline{38}$

VII. Reconciliation of Projected Income and Expenses_FY 2021_ $\underline{39}$ 


\section{INTRODUCTION ${ }^{1}$}

1. This paper reviews the Fund's income position for FY 2021 and FY 2022. It updates the projections of the Fund's income position for FY 2021 and FY 2022 and proposes decisions for the current and next financial year. No change is proposed in the margin for the rate of charge that was established in April 2020 for the period FY 2021-22. ${ }^{2}$ The lending income projections for FY 2021 and FY 2022 are broadly unchanged from the projections in the interim update of the Fund's income position for FY 2021. Overall net income (including the retained income of the EA) of about SDR 4.1 billion is now projected for FY 2021, up from SDR 3.2 billion in the interim update, mainly reflecting an increase in estimated remeasurement gains under IAS 19. The overall net income projections for FY 2022 are broadly unchanged from the interim projections.

\section{The paper reflects feedback from Executive Directors in the context of recent} income-related papers. The paper incorporates the outcome of the March 8 informal session to engage with Executive Directors on the timing of initiating payouts from the Endowment Subaccount (EA) and on the presentation of pension-related gains and losses. It also proposes a formal endorsement of the approach for the provisioning for impairment losses that was discussed by the Executive Directors in October 2020. It is also informed by the discussions in the informal session with Executive Directors on April 1 on the review of concessional financing and policies to suspend the reimbursement of PRGT administrative expenses by one year.

3. The paper is structured as follows: The first section reviews the FY 2021 income position and the main changes from the April 2020 projections, and the interim update. The second section makes proposals on the disposition of FY 2021 net income and placement to reserves. The third section updates the income projections for FY 2022, discusses the margin for the rate of charge for that period, and reviews the projected burden sharing adjustments.

\section{REVIEW OF THE FY 2021 INCOME POSITION}

4. Net operational income of the GRA, after adjusting for a large pension-related (IAS 19) gain is now projected at about SDR 3.5 billion for FY 2021; significantly higher than the initial estimate of SDR 1.3 billion in April 2020 (see Table 1, Line D). Total lending income is projected to be slightly lower than the April 2020 projections, reflecting mainly fewer disbursements.

Investment income is similar to the April estimates as higher Fixed-Income Subaccount returns are projected to offset the impact of the proposed delay in the EA payout; and lower net administrative expenditures than in prior projections are expected to lead to higher net income. The pension-related (IAS 19) remeasurement gain is expected to make a positive contribution of about

\footnotetext{
${ }^{1}$ Prepared by a team comprising Alexander Attie, Marco Cobanera, Fiona Delaney, Emer Fleming, Martin Gororo, Courage Gumbanjera, Bilal Khan, David Moore, Diviesh Nana (lead), Amadou Ndiaye, Victoria Nichipurenko, Enosa Okosodo Odibo, Breno Oliveira, Diana Parra, Vidhya Rustaman, Charles Xie, Jesse (Jinyong) Yang, Jessie Yang, Edda Zoli, and Vera Zolotarskaya, under the guidance of Maria Manno and Simon Bradbury (all FIN).
}

${ }^{2}$ A New Rule for Setting the Margin for the Basic Rate of Charge (11/22/11), was adopted by the Executive Board in December 2011 and was first applied in setting the margin for the rate of charge for FY 2013-14. 
SDR 2.5 billion. Compared with the interim projections, the GRA net income is expected to be SDR 0.8 billion higher reflecting mainly the pension-related (IAS 19) gains.

5. The Fund's overall net income for FY 2021 is now projected at SDR 4.1 billion, after taking into account the retained investment income of the EA (Table 1). The higher estimate compared with the interim and April projections reflects the substantial pension-related remeasurement gains projected for FY 2021 and the strong performance of the EA portfolio during the year. The main components of the projected FY 2021 result are outlined below (see Annex $V$ for underlying assumptions):

Total operational lending income is projected to be SDR 2 billion, about SDR 47 million lower than the April 2020 estimate (Table 1, Line A).

- Margin income is expected to be SDR 93 million lower than projected in April 2020, consistent with a SDR 9.3 billion lower average projected stock of credit outstanding, mainly attributable to certain purchases taking place later than expected or no longer expected to take place as anticipated in April. ${ }^{3} \mathrm{~A}$ rephasing of drawings under existing arrangements, advance repurchases, and the expiration of arrangements with undrawn balances also contribute to the lower projected margin income, offset by demand under recently approved new arrangements and instruments.

- Service charges are projected at SDR 123 million, broadly in line with the April 2020 estimate.

- Commitment fees are projected at SDR 70 million, SDR 30 million higher than the initial estimate in April 2020, following the recognition of commitment fee income from Argentina's cancellation of its stand-by arrangement in July $2020 .{ }^{4}$

- Surcharges are projected to be about SDR 18 million higher than the April 2020 estimate, due mainly to surcharges expected from approved new arrangements, partly offset by lower surcharges resulting from delayed purchases and purchases no longer expected to take place as previously anticipated.

- Compared with the interim projections, lending income (margin income, service charges, and surcharge income) is now expected to be SDR 35 million lower (Table 1). Under the current desk survey scenario for potential Fund lending demand, new programs expected in late FY 2021 in the interim update have been deferred to FY 2022, lowering lending income projections.

Investment Income-Fixed-Income Subaccount (FI): Investment income from the FI is currently projected to reach SDR 102 million, SDR 51 million higher than the April estimate, reflecting mainly a

\footnotetext{
${ }^{3}$ In the April projection, purchases were mainly scheduled to take place in the early part of the year, resulting in higher projected average credit outstanding for FY 2021.

${ }^{4}$ Commitment fee income is only recognized at the expiration or cancellation of an arrangement in accordance with accounting principles.
} 
Table 1. Projected Income and Expenditures-FY 2021

(in millions of SDRs)

\begin{tabular}{|c|c|c|c|c|}
\hline & & \multicolumn{3}{|c|}{ FY2021 } \\
\hline & & \multicolumn{3}{|c|}{. . . . . - (New Format - IAS 19) ${ }^{1} \ldots \ldots$} \\
\hline & & $\begin{array}{c}\text { Initial } \\
\text { Projections - } \\
\text { Supplement }^{2} \\
\end{array}$ & $\begin{array}{c}\text { Interim } \\
\text { Projections }\end{array}$ & $\begin{array}{c}\text { Current } \\
\text { Projections }\end{array}$ \\
\hline & Operational income & 2,220 & 2,273 & 2,102 \\
\hline & Lending income & 2,039 & 2,027 & 1,992 \\
\hline & Margin for the rate of charge & 961 & 873 & 868 \\
\hline & Service charges & 125 & 142 & 123 \\
\hline & Commitment fees & 40 & 70 & 70 \\
\hline & Surcharges & 913 & 942 & 931 \\
\hline & Investment income & 105 & 173 & 102 \\
\hline & Fixed-Income Subaccount (reserves) & 51 & 113 & 102 \\
\hline & Endowment Subaccount payout ${ }^{3}$ & 54 & 60 & 0 \\
\hline & Interest free resources ${ }^{4}$ & 7 & 7 & 5 \\
\hline & SCA- 1 and other & 7 & 7 & 5 \\
\hline & Reimbursements & 69 & 66 & 3 \\
\hline & SDR Department & 3 & 3 & 3 \\
\hline & PRG Trust ${ }^{5}$ & 66 & 63 & 0 \\
\hline & Expenses & 924 & 1,118 & 1,127 \\
\hline & Net administrative expenditures & 866 & 835 & 808 \\
\hline & Capital budget items expensed & 9 & 9 & 8 \\
\hline & Depreciation & 49 & 49 & 49 \\
\hline & Net periodic pension cost after funding (IAS 19) ${ }^{1}$ & 0 & 225 & 262 \\
\hline & Net operational income (A-B) & 1,296 & 1,155 & 975 \\
\hline & Pension-related (IAS 19) remeasurement gains/(losses) ${ }^{1}$ & 0 & 1,561 & 2,497 \\
\hline & Net operational income after IAS 19 adjustment & 1,296 & 2,716 & 3,472 \\
\hline & Endowment Subaccount - Retained income & 116 & 506 & 606 \\
\hline & Net income position & 1,412 & 3,222 & 4,078 \\
\hline \multicolumn{5}{|c|}{ Memorandum Items: } \\
\hline & Fund credit (average stock, SDR billions) & 96.1 & 87.3 & 86.8 \\
\hline & SDR interest rate (average, in percent) & 0.1 & 0.1 & 0.1 \\
\hline & US\$/SDR exchange rate (average) & 1.37 & 1.42 & 1.42 \\
\hline & Precautionary balances (end of period, SDR billions) & 17.8 & 18.7 & 19.5 \\
\hline \multicolumn{5}{|c|}{ Finance Department and Office of Budget and Planning. } \\
\hline \multicolumn{5}{|c|}{$\begin{array}{l}\text { Imes a delay in the payout for one more year to FY 2022. Directors broadly supported the approach to delay the payout at the } \\
\text { nal meeting in March } 2021 \text {. } \\
\text { rest free resources reduce the Fund's costs and therefore provide implicit returns. Since the Fund invests its reserves in the IA to } \\
\text { higher return, the interest free resources retained in the GRA are mainly attributable to the SCA-1, unremunerated reserve } \\
\text { he positions not represented by gold holdings, and GRA income for the year not transferred to the IA. These resources } \\
\text { e members' reserve tranche positions and the Fund's remuneration expense or increase interest income if reflected in SDR } \\
\text { igs of the GRA, resulting in implicit income for the Fund. } \\
\text { Imes a one-year suspension of reimbursement of FY } 2021 \text { PRGT administrative cost. }\end{array}$} \\
\hline
\end{tabular}


narrowing of credit spreads since the beginning of the financial year that contributed to the strong performance of the Tranche 1 portfolio to end-February. In contrast, a sharp government bond sell-off in late February offset some of the earlier gains resulting in current projections being lower than the interim by about SDR 11 million. The FY 2021 projections remain highly uncertain given ongoing bond market volatility.

\section{EA Payout and Retained Investment Income-Endowment Subaccount (EA):}

- A key feature of the EA payout policy framework agreed by the Executive Board in April 2018 was to delay payouts for three years to build a cushion of retained investment income (Annex III and Annex IV). It was also agreed that the size of the cushion would be reassessed at the end of the three-year period (FY 2021).

- During the informal discussion in March 2021 of the interim update, Executive Directors broadly supported a delay in the commencement of the EA payout by an additional year. This would allow the payout decision to be informed by the outcome of the IA review in FY 2022. ${ }^{5}$ The IA review could result in modifications to the EA investment strategy and the long-term return outlook, which would impact the calculation of the initial USD payout value under the current EA payout policy framework. ${ }^{6} \mathrm{~A}$ further delay would also allow more time for a potential increase of the EA cushion that would better insulate the portfolio against large adverse market events. A sizeable cushion would also reduce the risk of a stop-start scenario in the future if the maximum payout limit is triggered (Annex IV). In addition, a one-year delay in initiating EA payouts would have only a modest impact on the Fund's net operational income and precautionary balances in FY 2021. ${ }^{7}$ Staff therefore proposes that EA investment income for FY 2021 be retained in the EA rather than transferred to the GRA to be used for administrative expenses.

- EA investment income of SDR 606 million projected for FY 2021 is substantially higher than the previous estimate in April and reflects mainly the strong equity market performance through end-February that reversed the sharp decline earlier in March 2020. EA income for the year is estimated to be SDR 100 million higher than the interim projections due mainly to the strengthening of the US dollar against the SDR since the interim update.

Implicit returns on interest-free resources: The updated implicit returns on interest-free resources are projected to be SDR 5 million, in line with the prevailing low interest rate environment, and an average SDR interest rate for FY 2021 that is consistent with the earlier projection of about 0.1 percent.

Reimbursements to the GRA: In accordance with the Articles of Agreement, the GRA has to be reimbursed in respect of (i) the expenses for conducting the business of the SDR Department (Article

\footnotetext{
${ }^{5}$ The 5 -yearly review of the EA and the FI has been brought forward by one year to take into consideration market developments following the COVID-19 crisis, and to align with the Review of the Trust Assets Investment Strategy.

${ }^{6}$ Under the payout framework approved by the Board in 2018, the calculation of the initial USD payout would be aligned with prevailing market conditions and future payout amounts would increase annually by the GED.

7 The overall net income and the Fund's total reserve position would not be affected in FY 2021 and could be slightly higher in FY 2022 assuming higher returns from funds retained in the EA compared with the FI.
} 
$\mathrm{XVI}$, Section 2); and (ii) the expenses of administration of the Special Disbursement Account (SDA) on the basis of reasonable estimates (Article V, Section 12(i)). ${ }^{8}$ Moreover, under the Executive Board decision approving the PRGT, the PRGT has to reimburse the GRA for the expenses of administering the PRGT (i.e., all administrative expenses not only those related to SDA resources). ${ }^{9}, 10$

- The expenses of conducting the business of the SDR Department in FY 2021 are estimated at SDR 3.43 million (proposed Decision 1), broadly in line with the earlier estimate. ${ }^{11}$

- The PRGT administrative expenses for FY 2021 are estimated at SDR 86.65 million, about SDR 20 million higher than earlier estimates in SDR terms, reflecting mainly the surge in lending since the onset of the pandemic. In view of the impact of the significantly increased lending volume of the PRGT in the context of the COVID-19 crisis on the self-sustainability of the PRGT, and given the broad support for a suspension of reimbursement for PRGT administrative expenses at the recent informal session with Executive Directors on the review of concessional financing and policies, staff proposes a temporary one-year suspension of the reimbursement of PRGT administrative expenses (proposed Decision 2) for FY 2021. Temporary suspension of reimbursement to the GRA for PRGT administrative expenses is permissible under the Fund's new income model adopted in 2008 and the three-pillar framework for the self-sustained PRGT adopted in 2012 to help restore the lending capacity of the PRGT. A one-year suspension would offset part of the costs to the PRGT due to the unprecedented level of PRGT lending since the COVID-19 crisis. This suspension, while reducing the GRA income by an amount equivalent to an estimated SDR 86.65 million, would allow for this amount to be retained in the PRGT reserve account, boosting the PRGT reserve coverage and helping generate additional PRGT subsidy resources. ${ }^{12}$ The issue of possible multi-year waivers of reimbursements to support PRGT lending capacity will be taken up as part of the concessional financing review.

\footnotetext{
${ }^{8}$ In accordance with Article V, Section 12(f) and (g), SDA resources can be used for various purposes, as specified in the Articles of Agreement, including transfers to the GRA for immediate use in operations and transactions, transfers to the IA, or operations and transactions that are not authorized by other provisions of the Articles but are consistent with the purposes of the Fund, in particular to provide balance of payments assistance on special terms to low-income member countries. SDA resources include both assets held within the SDA and assets from the SDA, which have been contributed to the various trusts administered by the Fund as trustee, including the current PRG, PRG-HIPC and CCR Trusts.

${ }^{9}$ See Decision No. 8760-(87/176), adopted December 18, 1987.

10 The process of estimating SDR Department and PRGT administration expenses relies primarily on the Fund's Analytic Costing and Estimation System (ACES) and estimates use lagged actual data for Q4 costs.

${ }^{11}$ Consistent with paragraph 5(b) of Schedule $M$ to the Articles of Agreement, the SDRs considered for calculating the assessment do not include SDR 16 million that, due to the overdue financial obligations of one member, are being held in an escrow account pursuant to paragraph 5(a) of Schedule M.

12 Staff does not consider that the PRGT has any expenses related to the administration of SDA assets in the PRGT
that require reimbursement under Article V, Section 12(i). The Fund has fully "waived" PRGT reimbursement during
the FY 2005-2009 period and the FY 2010-2012 period when no reimbursement from the PRGT reserve account to
the GRA was made for the cost of administering the trust, and during the latter period, the amount equivalent to
such cost was instead transferred from the PRGT reserve account to the PRGT general subsidy account. Earlier, for the
period of FY 1998-2004, the Fund also decided to suspend the PRGT reimbursement and transfer the equivalent
amounts from the PRGT reserve account to finance the HIPC initiative. The suspension was taken on the
}

(continued) 
- Consistent with the practice in past years, staff does also not propose reimbursements of administrative expenses related to SDA resources in the Catastrophe Containment and Relief (CCR) and PRG-HIPC Trusts for FY 2021. The fact that SDA assets co-finance debt relief initiatives administered by the Fund on the basis of Article V, Section 2(b) that are otherwise funded with donor contributions and do not exclusively rely on SDA resources, does not trigger any additional costs that the Fund would not already bear under its other activities. ${ }^{13}$

Expenses: Total expenses of the GRA are estimated to be about SDR 203 million higher than the April 2020 projection (Table 1, Line B).

- Net administrative expenditures are projected to be lower by about SDR 58 million in FY 2021. About half the decline can be attributed to a weaker annual average US dollar/SDR exchange rate since April; the remaining difference largely reflects structural savings, and excludes transitional travel and reprioritization savings. ${ }^{14}$ Similar to the interim update, the weakening of the US dollar against the SDR so far this year has increased the average conversion rate from US $\$ 1.37$ per SDR assumed in the April projection to US $\$ 1.42$ per SDR, reducing administrative expenses in SDR terms by about SDR 31 million.

- Capital budget items expensed, and the depreciation charge are broadly in line with previous projections.

- Following the alignment of the pension-related gains and losses presentation in the paper with the financial statements, estimated net periodic pension costs after funding for FY 2021 are recategorized under expenses, increasing total expenses by about SDR 262 million. The large increase compared with actual prior year costs is attributable mainly to the lower discount rate used to calculate the service costs for the current year (Table 2).

\section{Pension-Related (IAS 19) Adjustment:}

6. The pension-related (IAS 19) gain results from the actuarial remeasurement of the Fund's post-employment benefits plans, which by end-February had been significantly impacted by a sharp rise in Plan asset values and the increase in discount rates since the beginning of the year. ${ }^{15}$ IAS 19 "Employee Benefits" is the International Financial Reporting Standard (IFRS) that deals with accounting for pension and other employee benefits. As discussed in

understanding that reimbursable expenses would only arise where PRGT principal loan disbursements would be funded with SDA resources, and that absent such use, the Fund may decide that the GRA bear the cost of the PRGT.

${ }^{13}$ In this regard it should be noted that the most direct costs related to SDA assets in the various trust are the investment management fees and any operational out-of-pocket expenses. These are borne by the assets as the investment managers deduct such fees/expenses from the investment returns attributed to these assets. Staff has initiated a review of past SDA reimbursements practices to ensure consistency in the treatment of SDA assets in the various trusts. The finalization has been delayed in view of more pressing demands on staff in response to the COVID-19 crisis. Staff plans to present its more detailed findings and recommendations to the Board in the context of the discussion on PRGT reimbursement in the final proposals under Review of Concessional Financing and Policies.

${ }^{14}$ See FY 2022-FY 2024 Medium-Term Budget paper (3/26/21).

15 Under IAS 19, the discount rate is determined by reference to market yields at the end of the financial year on high quality corporate bonds. The Fund's actuary (Willis Towers Watson) derives the Fund's discount rate from the FTSE Pension Discount Curve which is widely applied. 
Annex II, pension-related (IAS 19) gains and losses are volatile year-on-year but have tended to offset over time.

- During the informal discussion in March, Executive Directors broadly supported the presentational changes to the Fund's financial statements and income paper to isolate pension related volatility. From FY 2021, the Fund's Statement of Comprehensive Income will be presented in this year's financial statements as two separate statements, (i) a Statement of Income and (ii) a Statement of Comprehensive Income. The income tables in this paper are also presented in the new format which aligns more closely with the financial statement presentation (Table 1 and Table 3).

- An experience study to assess the suitability of the actuarial assumptions was performed in FY 2021 in accordance with the five-year review. Changes are expected to be approved by the Executive Board prior to the financial year-end and to be incorporated in the final actuarial calculations at year-end. The estimated FY 2021 pension-related adjustment includes an estimate of the effect of the expected changes to the grossing-up formula but do not incorporate any other changes which may be approved.

- The FY 2021 expected pension-related (IAS 19) adjustment comprises two elements:

(i) remeasurement gains/(losses) and (ii) the net periodic pension cost, net of funding.

- Remeasurement gains and losses result mainly from changes in the actuarially-assessed estimated future benefit obligation, and changes in the fair value of plan assets. The current year projections point to net actuarial remeasurement gains of SDR 2,497 million that are largely attributable to excess returns on plan assets, combined with an increase in the discount rate (Table 2).

- The revaluation projections of assets for the year are based on actual and estimated portfolio performance to end-February 2021, and the end-February discount rate is projected to the end of the year. As such they remain subject to considerable uncertainty and actual outcomes may be significantly different based on developments in the financial markets.

- The fair value of plan assets is volatile, as illustrated by recent market movements, and therefore remains unpredictable. The sharp rise in asset valuations reflects the gains recognized to end-February and mirrors the strong performance of financial markets since the beginning of the year. After allowing for the expected income on plan assets (included under the pension cost accrual in the table), the actuarially-determined remeasurement of plan assets is projected to lead to a positive contribution of SDR 2,002 million (Table 2). 


\begin{tabular}{|c|c|c|c|c|c|}
\hline \multicolumn{6}{|c|}{$\begin{array}{r}\text { Table 2. Reconciliation of Pension-Related } \\
\text { (in millions of SDRs) }\end{array}$} \\
\hline & \multirow{2}{*}{$\begin{array}{c}\text { FY } 2018 \\
\text { Actual } \\
\text { for year }\end{array}$} & \multirow{2}{*}{$\begin{array}{c}\text { FY } 2019 \\
\begin{array}{c}\text { Actual for } \\
\text { year }\end{array}\end{array}$} & \multirow{2}{*}{$\begin{array}{c}\text { FY } 2020 \\
\begin{array}{c}\text { Actual for } \\
\text { year }\end{array}\end{array}$} & \multicolumn{2}{|c|}{ FY 2021} \\
\hline & & & & $\begin{array}{c}\text { Actual end- } \\
\text { Dec 31, } \\
2020 \\
\end{array}$ & $\begin{array}{c}\text { Projected for } \\
\text { year }\end{array}$ \\
\hline Net periodic pension cost after funding (Accrual vs. Funding) & -140 & -125 & -91 & -225 & -262 \\
\hline Net periodic pension cost accrual & -274 & -263 & -238 & -332 & -419 \\
\hline Service cost - current & -274 & -273 & -310 & -271 & -407 \\
\hline Service cost - prior year (plan amendment) ${ }^{1}$ & 0 & 0 & 83 & 0 & 79 \\
\hline Interest expense on pension liability & -340 & -355 & -377 & -223 & -335 \\
\hline Expected income on pension asset ${ }^{2}$ & 340 & 365 & 366 & 162 & 244 \\
\hline Pension funding & 133 & 138 & 147 & 107 & 157 \\
\hline Remeasurement gains/(losses) & 381 & -365 & $-2,880$ & 1,561 & 2,497 \\
\hline Discount rate change & 129 & -301 & $-2,173$ & -645 & 450 \\
\hline 'Excess return' on assets ${ }^{2}$ & 594 & -145 & -944 & 2,116 & 2,002 \\
\hline Exchange rate translation & 2 & 9 & -5 & 90 & 45 \\
\hline Experience adj & 0 & 0 & -15 & 0 & 0 \\
\hline Other ${ }^{3}$ & -344 & 72 & 257 & 0 & 0 \\
\hline Total IAS 19 gains/(losses) & 241 & -490 & $-2,971$ & 1,336 & 2,235 \\
\hline Discount rate - at end of period (in percent) & 4.05 & 3.86 & 2.73 & 2.45 & 2.92 \\
\hline \multicolumn{6}{|c|}{$\begin{array}{l}\text { Source: Willis Towers Watson and IMF Finance Department } \\
{ }^{1} \text { FY21: Estimate of the impact of changes to the grossing-up formula. } \\
{ }^{2} \text { Total income from plan assets comprises two components for financial reporting purposes: i) the expected income } \\
\text { on plan assets calculated using the discount rate, and included in the pension cost and ii) a gain or loss included in } \\
\text { remeasurement losses that is in 'excess' of this expected income. } \\
{ }^{3} \text { FY20: CCBR salary scale assumption adjustment; FY18: relates to adoption of } 2017 \text { UN mortality table. }\end{array}$} \\
\hline
\end{tabular}

- Recent trends in market interest rates have translated into an increase in the discount rate. The actuarially determined remeasurement of future obligations is expected to result in a gain in FY 2021, reflecting the 19 basis points increase in the discount rate to 2.92 percent as of end-February 2021 (Table 2). ${ }^{16}$

- The net periodic pension cost after funding amounts to SDR 262 million and represents mainly the difference between (i) accruals comprising the actuarially determined annual service cost expense (the increase in obligations under the staff retirement plan stemming mainly from an additional year of staff service of SDR 407 million), an estimated gain from the expected changes to the grossing-up formula following completion of the experience study conducted in FY 2021 of about SDR 79 million, the net interest cost of SDR 91 million, and (ii) the funding (cash appropriation) for the year projected at SDR 157 million.

- Since the adoption of IAS 19 for pension and related benefits accounting, forward-looking projections about the demographic and other assumptions, and returns on the asset portfolio, have not been built into the income scenarios, due to the volatility, and hence unpredictability, of these assumptions.

\footnotetext{
16 Yields on high quality U.S. corporate bonds have trended higher since January 2021; and based on the current level of the discount rate, a 100 basis point change can increase or decrease the value of the pension liability by 17 to 19 percent. The end-February rate is projected to year end.
} 
7. The actual outturn for the FY 2021 pension-related (IAS 19) adjustment remains highly uncertain. The pension-related adjustment for FY 2021 will only be finalized after year-end and the impact on net income or loss will be reported in the Fund's annual financial statements scheduled for completion in June 2021. In accordance with accounting standards, the pension-related gain or loss will be calculated using the discount rate, asset returns, and other inputs as of April 30 (the year-end reporting date). Paragraph 19 includes a sensitivity analysis of the projected net gain to the IAS 19 gains and losses.

\section{Credit Risk:}

8. IFRS 9 "Financial Instruments" which became effective for the Fund in FY 2019 requires an impairment assessment to be conducted using the expected credit loss model. The Fund's framework for assessing the need to provision has been adapted to comply with IFRS 9 and was designed to reflect the unique nature of the Fund's lending. ${ }^{17}$ Under the new framework, and considering the Fund's multilayered framework for managing credit risk, cases where the recording of a material provisions for an impairment loss may need to be considered are expected to remain rare. Staff is in the process of finalizing the IFRS 9-related country assessments and at this stage no impact is expected on the FY 2021 annual financial statements. Staff plans to brief the Board again before the FY 2021 annual financial statements are finalized.

9. An informal meeting with Executive Directors to discuss provisioning for impairment losses took place in October 2020. Directors underscored the importance of ensuring the Fund's compliance with IFRS 9 and noted that cases where provisioning may need to be considered by the Fund should remain rare due to the unique nature of the Fund's lending and its multilayered framework for managing credit risks. Directors broadly supported the approach laid out in the paper for addressing cases of impairment, including the use of provisioning, and incorporating Board consultation before any such provision is recorded and reported. As the October meeting was informal, staff agreed to come back to the Board for formal endorsement of the approach before the conclusion of the next financial reporting cycle. In light of this, staff proposes that the approach be formally endorsed in the Summing Up of the Board discussion of this paper.

\section{DISPOSITION DECISIONS}

10. As in previous years, the Executive Board needs to consider certain decisions on the disposition of income for FY 2021. These cover: the use of investment income earned in FY 2021 from the Fixed-Income Subaccount, which impacts the determination of GRA net operational income in FY 2021; the placement of net income to reserves and the allocation between the special and general reserve; ${ }^{18}$ and the transfer of currencies from the GRA to the IA. These disposition

\footnotetext{
17 See Annex III, Review of the Fund's Income Position for FY 2019 and FY 2020 (03/19/19) for a fuller discussion on the implementation of the new standard in the Fund.

18 Under Article XII, Section 6(b), the Fund may use the special reserve for any purpose for which it may use the general reserve, except that balances in the special reserve may not be used for distribution to Fund members.
} 
considerations and decisions are presented in Figure 1, and discussed below, beginning with the disposition of IA investment income.

\section{Figure 1. Summary of Proposed Disposition Decisions}

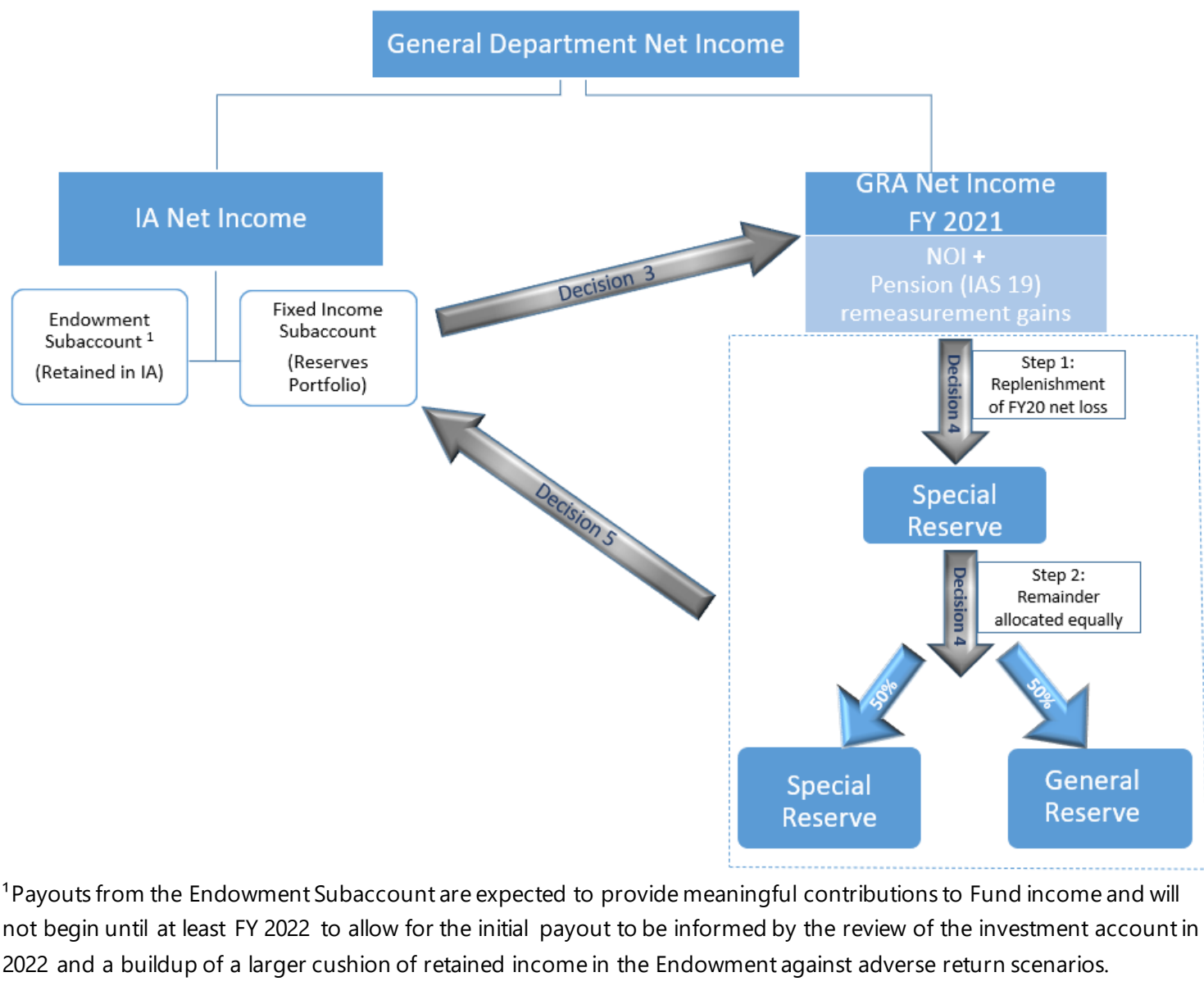

11. The use of IA income is guided by the Fund's Articles. Under Article XII, section 6 ( $f$ ) (iv), investment income from the IA may be invested, held in the IA, or used for meeting the expenses of conducting the business of the Fund. ${ }^{19}$ Staff proposes that income in the subaccounts of the IA be used as follows:

- Fixed-Income Subaccount: Consistent with past practice, staff proposes that the estimated FY 2021 income be transferred to the GRA to be used towards meeting the expenses of the Fund (proposed Decision 3). By so doing the IA income will contribute to the GRA net income, which will be placed to the Fund's reserves as indicated in Figure 1; and

- Endowment Subaccount: Staff proposes that any net investment income earned in the EA in FY 2021 be fully retained in the endowment and not be transferred to the GRA to be used for meeting administrative expenses. Based on current projections for FY 2021, this would imply that EA projected income of about SDR 606 million, reflecting actual performance to

\footnotetext{
${ }^{19}$ Article XII, Section 6 (f)(iv). The Board could also, by a 70 percent majority of the total voting power, decide to reduce the amount of the investment in the IA (Article XII, Section 6 ( $f(v)$ )).
} 
end-February, would be retained and reinvested according to the investment strategy for the EA. An equivalent amount would be reflected in the special account for IA retained earnings, raising cumulative retained earnings of the IA (all attributable to the EA) to about SDR 1,814 million (proposed Decision 3).

\section{The Articles of Agreement require the Fund to determine annually how to allocate its} net income. The Articles permit the Fund's net income of the GRA to be either distributed to members or placed to reserves in accordance with the annual decision on the disposition of the Fund's net income. In accordance with the decision taken in FY 2018 by the Executive Board to review the allocation framework on a two-yearly cycle, a review was to have taken place in FY 2020. ${ }^{20,}{ }^{21}$ However, as there was a net loss last year, the review was deferred until the next year in which the Fund has positive net income after having replenished cumulative losses charged to the special reserve in the intervening periods. In light of the positive net income projected for FY 2021, the Fund is now in a position to replenish the losses incurred in FY 2020.

\section{In view of the ongoing discussions with the Executive Board on the treatment of} IAS 19 gains and losses, staff proposes to postpone the review of the allocation framework by another year. Specifically, at the informal session on March 8, 2021 to engage Executive Directors on the interim update of the Fund's income position for FY 2021, staff discussed two possible options for the treatment of IAS 19 remeasurement gains and losses, to better isolate their volatility. The first option would be to separately identify and 'ring-fence' the IAS 19 remeasurement gains/losses in the special reserve. The second option would be to create an additional account outside of the special and general reserve to capture future accumulated IAS 19 remeasurement gains/losses. This would be a separate equity or retained earnings type account recognized as part of the GRA resources. A variety of views were expressed by the Board on the merits of both options and on maintaining the status quo, and based on the Board's initial feedback, staff will undertake further analysis of both options.

\section{A Board decision on the treatment of IAS 19 gains and losses under either of the above two options would have implications for the special and general reserve and the} allocation framework. The two options would imply an allocation of the IAS 19 remeasurement gains/losses either to the special reserve or to a separate account. Since either option would change the income allocation framework, staff recommends a deferral of the review of the framework to FY 2022, after a decision on whether to pursue one of the two options for IAS 19 or to maintain the status quo, has been made.

\footnotetext{
${ }^{20}$ Review of the Fund's Income Position for FY 2018 and FY 2019-20 (04/05/18).

21 See Box 2, Review of the Fund's Income Position for FY 2019 and FY 2020 (03/19/19). 


\section{For FY 2021, staff proposes to first allocate to the special reserve net income} equivalent to the FY 2020 loss, and then place the remaining balance equally between the special and general reserves (see proposed Decision 4). Last year the net loss of SDR 1.5 billion was fully charged to the special reserve, in accordance with the 1957 Board decision that "any administrative deficit for any fiscal year of the Fund shall be written off first against this reserve". The loss allocation resulted in a decline in the special reserve from SDR 5.7 billion to SDR 4.2 billion. Allowing a complete recovery of the reduction in the special reserve in FY 2020 would be consistent with the Fund's recent practice. ${ }^{22} \mathrm{~A} 50 / 50$ split of the remaining net income between the two reserves, after the special reserve has been replenished, would continue the approach used from FY 2016 to FY 2019, pending a review of the framework.

\section{GRA net income of SDR 3.5 billion projected for FY 2021 comprises net operating} income of about SDR 1 billion and an estimated remeasurement gain of SDR 2.5 billion (Table 1). Staff proposes to first allocate income of SDR 1.5 billion to the special reserve to replenish the loss incurred in FY 2020, and to allocate the remaining SDR 2 billion equally between the special and general reserve. The first part of this allocation would increase the special reserve from SDR 4.2 billion to its end-FY 2019 level of SDR 5.7 billion, and the second part would increase the special reserve to SDR 6.7 billion. ${ }^{23}$ The general reserve would rise from SDR 10.8 billion to SDR 11.7 billion (Text Figure). The ratio of special to total reserves would increase to about 36 percent in FY 2021, broadly in line with the pre-loss ratio in $\mathrm{FY}$ 2019-but still below its long-term average (see Text Figure). The level of precautionary balances would increase by about SDR 3.5 billion to SDR 19.5 billion at the end of FY 2021, compared with the medium-term target of SDR 25 billion. ${ }^{24}$

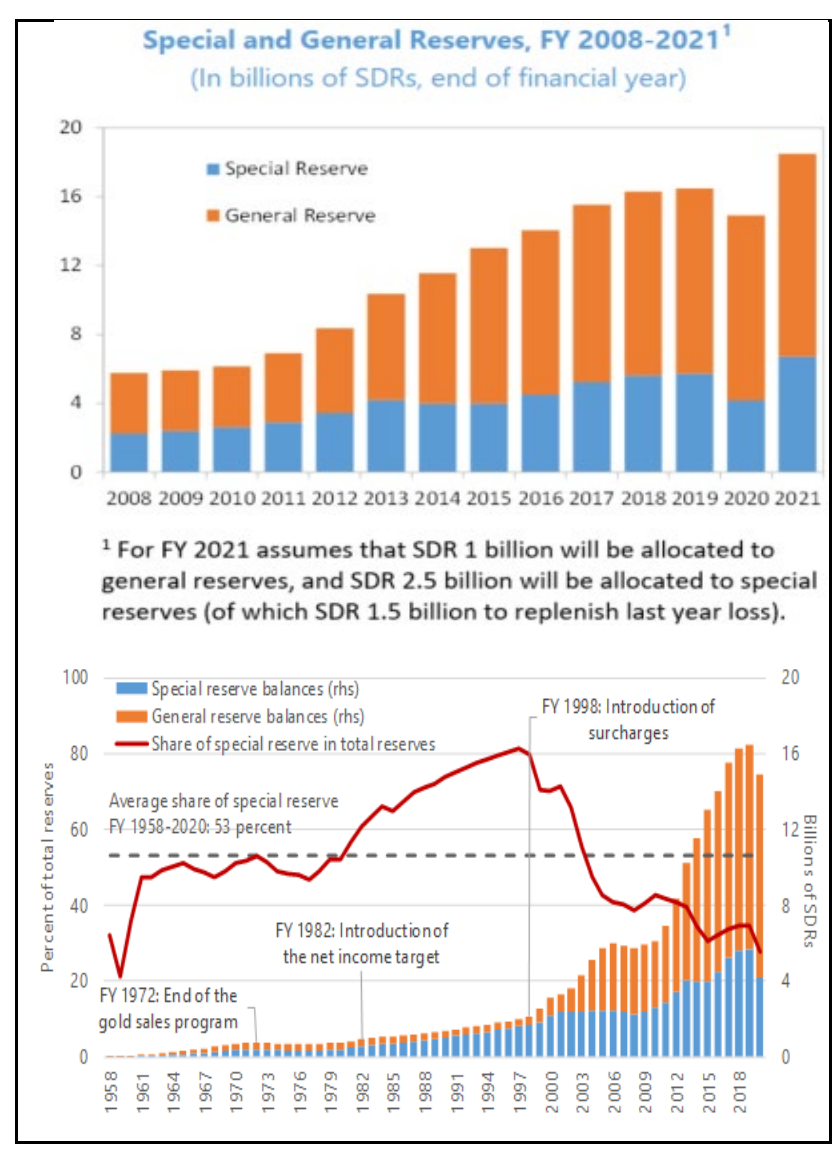

\footnotetext{
22 In FY 2009 the full net operating income of SDR 154 million was transferred to the special reserve reducing the prior years' cumulative deficit to SDR 54 million. In FY 2010 the full net operating income of SDR 227 million was transferred to the special reserve eliminating the deficit with the excess building up the special reserve.

${ }^{23}$ This amount does not include the part of the special reserve attributable to gold sales for the establishment of the endowment which is not considered to be part of the Fund's precautionary balances.

${ }^{24}$ Does not reflect the impact of any distribution of the SCA-1 in the context of the ongoing discussions on Sudan's debt relief.
} 
17. The placement of FY 2021 GRA net income to reserves provides scope for a further transfer of currencies to the Fixed-Income Subaccount. Article XII, Section 6(f)(ii) permits the transfer of additional GRA currencies to the IA if, at the time of the decision to make such transfer, the Fund's reserves are above the cumulative amount of previous transfers of currencies from the GRA to the IA. ${ }^{25}$ After the above placement, the combined balance in reserves is projected to total SDR 22.8 billion. This would remain above the net cumulative amount of transfers made thus far to the IA from the GRA of about SDR 20.9 billion. ${ }^{26}$

18. Accordingly, staff proposes to transfer currencies equivalent to the full amount of the increase in reserves from the GRA to the IA for investment in the Fixed-Income Subaccount (proposed Decision 5). ${ }^{27}$ This proposal is consistent with the assumption that the IA will over time achieve a higher return than the SDR interest rate.

19. Considering the sensitivity of the net income projections to several underlying assumptions, the final outcome for FY 2021 remains uncertain. ${ }^{28}$ In particular, the

pension-related gain for FY 2021 remains unpredictable, mainly due to its sensitivity to the discount rate and other factors such as the volatility of plan asset returns. Based on illustrative examples, a range of outcomes are possible, assuming that all other actuarial and income assumptions remained constant (Figure 2).

\footnotetext{
25 The cumulative amount is derived net of transfers out of the IA. In the past, windfall gold sales profits of SDR 2.45 billion had been transferred to the IA but these were subsequently transferred out during FY13-14, following a distribution of the general reserve to the membership, as part of the strategy for the creation of a self-sustained PRGT.

26 These totals include special reserves attributed to profits from the 2009-2010 gold sales of SDR 4.4 billion, which are not treated as part of the Fund's precautionary balances, and corresponding transfers to establish the gold endowment.

${ }^{27}$ A net transfer of about SDR 1.9 billion is estimated for FY 2021, after taking into account the loss of SDR 1.5 billion in FY 2020.

28 The projections remain susceptible to the unpredictability of key underlying assumptions including projections for lending, investment returns, exchange rates, etc.
} 


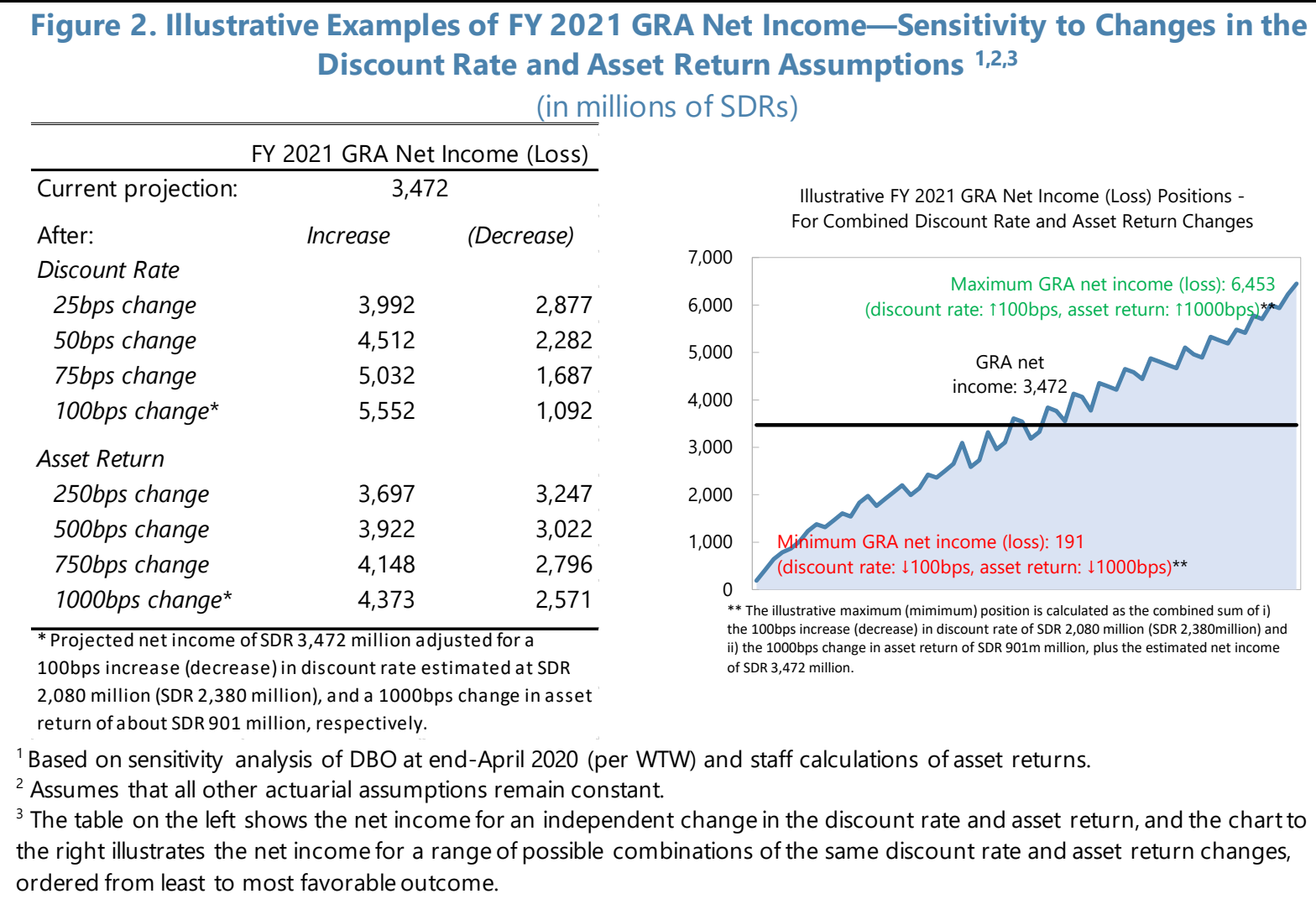

\section{FY 2022 INCOME OUTLOOK}

20. Based on current projections under the desk survey scenario, the income outlook for FY 2022, excluding the impact of the pension-related gain or loss, is expected to remain strong. Net income for FY 2022 is projected at about SDR 2.2 billion (Table 3). These projections assume the margin is maintained at 100 basis points (see below) and are sensitive to a number of factors as outlined below.

\section{A. Summary of Key Risks}

\section{Key risks to Fund income and finances associated with recent developments include,} cancellations and changes in the timing of purchases under existing and potential arrangements under the desk survey; fluctuations in the annual pension-related gain or loss as determined under IAS 19; uncertainties around the global interest rate environment and US dollar/SDR exchange rate path; and credit risk that is inherent in the Fund's unique role in the international financial architecture. More specifically: 
- Delays, rephasing or cancellation of purchases under existing and potential arrangements or early repurchases could lead to lower Fund income, though this risk could be mitigated by members seeking new Fund arrangements. ${ }^{29}$

- Changes in actuarial assumptions that impact the annual pension-related gain or loss under IAS 19 can be substantial and have a significant impact on overall Fund income and the accumulation of precautionary balances.

- While the broadening of non-lending income sources under the Fund's new income model is helping mitigate income risk, the low return environment and potential for further market volatility could imply downside risks to expected contributions from investment income.

- Regarding credit risks, staff is currently in the process of conducting IFRS 9-related impairment assessments for FY 2021.

\section{B. Key FY 2022 Income Outlook Factors}

22. The outlook for the Fund's net income in FY 2022 has been updated for the impact of changes in key assumptions, specifically investment returns and lending income. No projections are made for the pension-related (IAS 19) remeasurement gain or loss or periodic pension cost beyond FY 2021.

\section{Key factors that affect the FY 2022 income outlook are discussed below (see Table 3).}

A sensitivity analysis on the income effects of changes in some of the assumptions is presented in Table 4.

- Lending income. Margin and surcharge income are projected to be higher in FY 2022, reflecting mainly the potential new demand for Fund lending under the desk survey projections and continued disbursements under the current arrangements. Two precautionary arrangements that are scheduled to expire in FY 2022 are expected to contribute SDR 280 million in commitment fees.

- Fixed-Income Subaccount. ${ }^{30}$ Investment income is projected to be lower in FY 2022 at about SDR 61 million reflecting a lowering of the average expected returns projected for the portfolio (to about 0.33 percent).

- Endowment Subaccount. Total EA returns are projected to average about 3.5 percent over the medium term. However, over short time periods, income projections for the EA remain subject to considerable uncertainty given the high degree of volatility across the asset classes in which the EA is invested.

\footnotetext{
${ }^{29}$ A possible new SDR allocation could prompt some members to make early repurchases, lowering Fund income and reserve accumulation. However, staff did not observe any significant use of SDRs in early repurchases or repayments of Fund credit following the last general allocation in 2009.

30 The balance of the Fixed-Income Subaccount corresponds to the investment of the Fund's reserves except for the gold profits and any currencies retained in the GRA.
} 
Table 3. Projected Income Sources and Uses-FY 2021-2022

(in millions of SDRs)

\begin{tabular}{|c|c|c|c|}
\hline & FY2020 & FY2021 & FY2022 \\
\hline & Actual & \multicolumn{2}{|c|}{ Projected } \\
\hline & \multicolumn{3}{|c|}{ 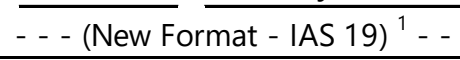 } \\
\hline A. Operational income & 2,313 & 2,102 & 2,956 \\
\hline Lending income & 1,884 & 1,992 & 2,715 \\
\hline Margin for the rate of charge & 667 & 868 & 990 \\
\hline Service charges & 91 & 123 & 104 \\
\hline Commitment fees & 374 & 70 & 280 \\
\hline Surcharges & 752 & 931 & 1,341 \\
\hline Investment income & 319 & 102 & 123 \\
\hline Fixed-Income subaccount (reserves) & 319 & 102 & 61 \\
\hline Endowment subaccount payout ${ }^{2}$ & 0 & 0 & 62 \\
\hline Interest free resources ${ }^{3}$ & 45 & 5 & 13 \\
\hline SCA- 1 and other & 45 & 5 & 13 \\
\hline Reimbursements ${ }^{4}$ & 65 & 3 & 105 \\
\hline SDR Department & 3 & 3 & 4 \\
\hline PRG Trust & 62 & 0 & 101 \\
\hline B. Expenses & 982 & 1,127 & 914 \\
\hline Net administrative expenditures & 833 & 808 & 843 \\
\hline Capital budget items expensed & 14 & 8 & 18 \\
\hline Depreciation & 44 & 49 & 53 \\
\hline Net periodic pension cost after funding (IAS 19) ${ }^{1}$ & 91 & 262 & 0 \\
\hline C. Net operational income (A-B) & 1,331 & 975 & 2,042 \\
\hline Pension-related remeasurement (IAS 19) gains/(losses) ${ }^{1}$ & $-2,880$ & 2,497 & 0 \\
\hline D. Net operational income/(loss) after IAS 19 adjustment & $-1,549$ & 3,472 & 2,042 \\
\hline Endowment subaccount investment income & 112 & 606 & 153 \\
\hline Special Disbursement Account net income/(loss) & -10 & 0 & 0 \\
\hline Net income position & $-1,447$ & 4,078 & 2,195 \\
\hline \multicolumn{4}{|l|}{ Memorandum items: } \\
\hline Fund credit (average stock, SDR billions) & 66.7 & 86.8 & 99.0 \\
\hline SDR interest rate (average, in percent) & 0.8 & 0.1 & 0.2 \\
\hline US\$/SDR exchange rate (average) & 1.38 & 1.42 & 1.44 \\
\hline Precautionary balances (end of period, SDR billions) & 16.0 & 19.5 & 21.5 \\
\hline
\end{tabular}

Source: Finance Department and Office of Budget and Planning

${ }^{1} \mathrm{New}$ format aligns the total pension-related (IAS 19) adjustment more closely with the financial statement presentation which apportions the net periodic pension cost to expenses and separately discloses the remeasurement gains and losses under Other Comprehensive Income $(\mathrm{OCl})$.

${ }^{2}$ Assumes a delay in the payout for one more year to FY 2022. Directors broadly supported the approach to delay the payout at the informal meeting in March 2021.

${ }^{3}$ Interest free resources reduce the Fund's costs and therefore provide implicit returns. Since the Fund invests its reserves in the IA to earn a higher return, the interest free resources retained in the GRA are mainly attributable to the SCA-1, unremunerated reserve tranche positions not represented by gold holdings, and GRA income for the year not transferred to the IA. These resources reduce members' reserve tranche positions and the Fund's remuneration expense or increase interest income if reflected in SDR holdings of the GRA, resulting in implicit income for the Fund.

${ }^{4}$ Assumes a one-year suspension of FY 2021 PRGT administrative cost reimbursements. No incremental costs are projected in managing the SDA resources in the CCR and PRG-HIPC Trusts. 
- During the informal discussion in March 2021, Executive Directors broadly supported a case to further delay the commencement of the EA payout by an additional year to FY 2022 (see above-EA Payout and Retained Investment Income). Projections continue to assume an initial payout of 1 percent, in line with the portfolio's prevailing return outlook, and an increase in US dollar terms by the GED rate each year thereafter (Annex III). Based on these assumptions, the estimated payout in FY 2022 would be equivalent to about SDR 62 million (equivalent to 1 percent of the US dollar value of the portfolio translated at the projected US dollar/SDR exchange rate for the year). Income in SDR terms retained in the EA and not distributed as a payout is expected to be equivalent to about SDR 153 million in FY 2022. ${ }^{31}$

- The forthcoming review of the IA in FY 2022 could result in modifications to the EA investment strategy and the long-term return outlook. In accordance with the discussion of the payout policy in March and the framework for guiding future payouts from the EA agreed by the Board (Annex III), ${ }^{32}$ the initial value of the payout would be reassessed and decided by the Board later in FY 2022.

- Interest-free resources and reimbursements. Income from interest-free resources is projected to be higher reflecting the expected uptick of the SDR interest rate path over the medium term. ${ }^{33}$ Projected reimbursements are based on the FY 2021 estimates and assume a resumption of the reimbursement of the GRA for the expenses of conducting the business of the PRG Trust pending the outcome of on-going discussions on the review of concessional lending.

- Expenditures.

- Net administrative expenses reflect the proposed FY 2022 budget that the Board will consider on April 23, which addresses near-term priorities through reallocation of resources. ${ }^{34}$ The budget is built on extensive reprioritization, savings-including from modernization-and a proposed temporary increase in the carry forward ceiling to address temporary crisis needs.

- Capital budget items expensed are expected to be higher and includes the impact of the proposed inclusion of recurring cloud subscription costs as the Fund proceeds to migrate from purchased or custom-built software to cloud-hosted platforms. ${ }^{35}$

- Periodic pension costs are not projected beyond FY 2021.

\footnotetext{
31 In line with the EA payout policy endorsed in April 2018, estimated investment income after the assumed payouts in FY 2022 is to be retained in the endowment for reinvestment and is therefore not included in the Fund's operational income (Annex III).

32 Endowment payout policy framework was endorsed by the Executive Board in April 2018 (see Review of the Fund's Income Position FY 2018 and FY 2019-2020 (04/05/18).

33 Projections do not reflect the impact on income of any distribution of the SCA-1 in the context of the ongoing discussions on Sudan's debt relief.

34 The net administrative budget projections show GED and a flat budget envelope, but do not yet reflect the proposed structural augmentation to be explored later this year.

35 FY 2022-FY 2024 Medium-Term Budget (3/26/21). 
- Pension remeasurement (IAS 19) gains and losses. Forward-looking projections about the demographic and other assumptions, and returns on the asset portfolio, are not built into the income scenarios, due to the volatility, and hence unpredictability, of these assumptions.

- Sensitivity Analysis. Projected income and expenses remain volatile in the near term and are particularly susceptible to changes in the underlying assumptions.

- The effect of changes in key income assumptions is summarized in Table 4.

\begin{tabular}{|lr|}
\hline \multicolumn{2}{|c|}{ Table 4. Sensitivity Analysis-Effect of Changes } \\
in Selected Assumptions on FY 2022 Projected Income \\
\hline \multicolumn{2}{c}{ (in millions of SDRs) } \\
\hline Increase/decrease in: \\
SDR interest rate by 50 basis points \\
Implicit returns ${ }^{2}$ & 34 \\
Margin for the rate of charge by 20 basis points ${ }^{2}$ & 198 \\
US dollar vis-à-vis SDR by five percent - Administrative expenses & 40 \\
US dollar vis-à-vis SDR by 1 US cent - Endowment Subaccount & 44 \\
Investment income margin by 50 basis points & 124 \\
\hline${ }^{1}$ Implicit returnson GRA interest-free resources. \\
${ }^{2}$ Based on the estimated average credit outstanding for FY 2022. \\
\hline
\end{tabular}

- The pension-related (IAS 19) gain or loss is highly unpredictable and can be significant: on the asset side, performance can be very volatile, and on the liability side, the defined benefit obligation (DBO) is highly sensitive to the underlying actuarial assumptions, in particular the discount rate.

\section{Review of the Margin for the Rate of Charge}

\section{Under Rule I-6(4), the Executive Board sets the margin over the SDR interest rate for a} period of two financial years. The level of the margin should be adequate to cover the Fund's intermediation costs, taking into account income from service charges, and help build up the Fund's reserves, considering the existing level of precautionary balances and the expected contribution from surcharges and commitment fees. At the same time, the level of the margin should ensure that the Fund's borrowing costs remain appropriately aligned with long-term credit market conditions. The rule also permits that, in exceptional circumstances, the margin may be set at a level other than that required to cover intermediation expenses and accumulate reserves.

\section{In April 2020, Directors supported maintaining the margin for the basic rate of charge} at 100 basis points for the period FY 2021-2022. At the time, Directors considered the level of the margin to be broadly aligned with long-term credit market conditions. Directors also acknowledged continued constraints to the Fund's non-lending income and that a portion of the Fund's non- 
lending activities will need to continue to be financed by income from the margin, thereby reducing its contribution to the Fund's reserve accumulation. ${ }^{36}$

26. While the margin is set for a two-year period, Rule I-6(4) calls for a comprehensive review of the Fund's income position before the end of the first year. The Executive Board may adjust the margin in the context of such review but, to provide for stability and predictability, only if this is warranted in view of fundamental changes in the underlying factors relevant for the establishment of the margin at the start of the two-year period.

27. Staff does not propose any change in the level of the margin in FY 2022. As discussed further below, staff is of the view that there has been no fundamental change in the underlying factors relevant for setting the margin since the last review, and therefore no change is proposed for FY 2022. Completion of the review is proposed in Decision 6.

\section{Coverage of Intermediation Costs}

28. Lending income is projected to remain substantially in excess of intermediation costs, in FY 2021. ${ }^{37}$ Income from service charges is projected at US\$175 million in FY 2021 (Table 5, row B). An unchanged margin of 100 basis points would provide further margin income of about US $\$ 1,233$ million. These amounts compare with estimated intermediation costs of about US\$141 million in FY 2021 (Table 5, row A). Fund-wide intermediation costs related to generally available facilities (GAF) are derived using the Fund's Analytic Costing and Estimation System (ACES). They cover direct personnel, travel, and other administrative expenses, as well as indirect support and governance costs. A proportion of capital spending is also added. Estimated FY 2021 costs are higher than earlier projections, reflecting the sharp increase in lending operations after the onset of COVID-19 (both concessional and non-concessional).

29. Commitment fees for non-drawing arrangements and surcharges are also projected to make substantial further contributions to the Fund's lending income and reserve

accumulation (see below). Income from commitment fees and surcharges in FY 2021 are estimated at about US $\$ 99$ million and US $\$ 1,322$ million, respectively (Table 5, row E and F), broadly in line with prior year projections.

\footnotetext{
36 The Executive Board has consistently set the margin under the exceptional circumstances clause since the amended Rule I-6(4) was first implemented as part of the Fund's New Income Model. The rule was designed to move away from reliance on lending income for financing the Fund's non-lending activities with the expectation that these would be covered by the Fund's non-lending income. However, investment income, the main source of the Fund's non-lending income, remains constrained by low global interest rates. Payouts from the gold-profits-funded endowment are also expected to provide a meaning ful contribution to Fund income over the long term, but are not assumed to begin until FY 2022 to allow for a buildup of a greater cushion of retained income in the endowment against adverse return scenarios.

${ }^{37}$ Commitment fees are included in the analysis as a source of income that contributes to reserve accumulation. Under this approach, the analysis in setting the margin is insulated from the unpredictability of commitment fees. See paragraphs 19-20 in A New Rule for Setting the Margin for the Basic Rate of Charge (11/22/11).
} 
Table 5. Income from the Margin and Reserve Accumulation ${ }^{1}$

(in millions of US Dollars, unless otherwise indicated)

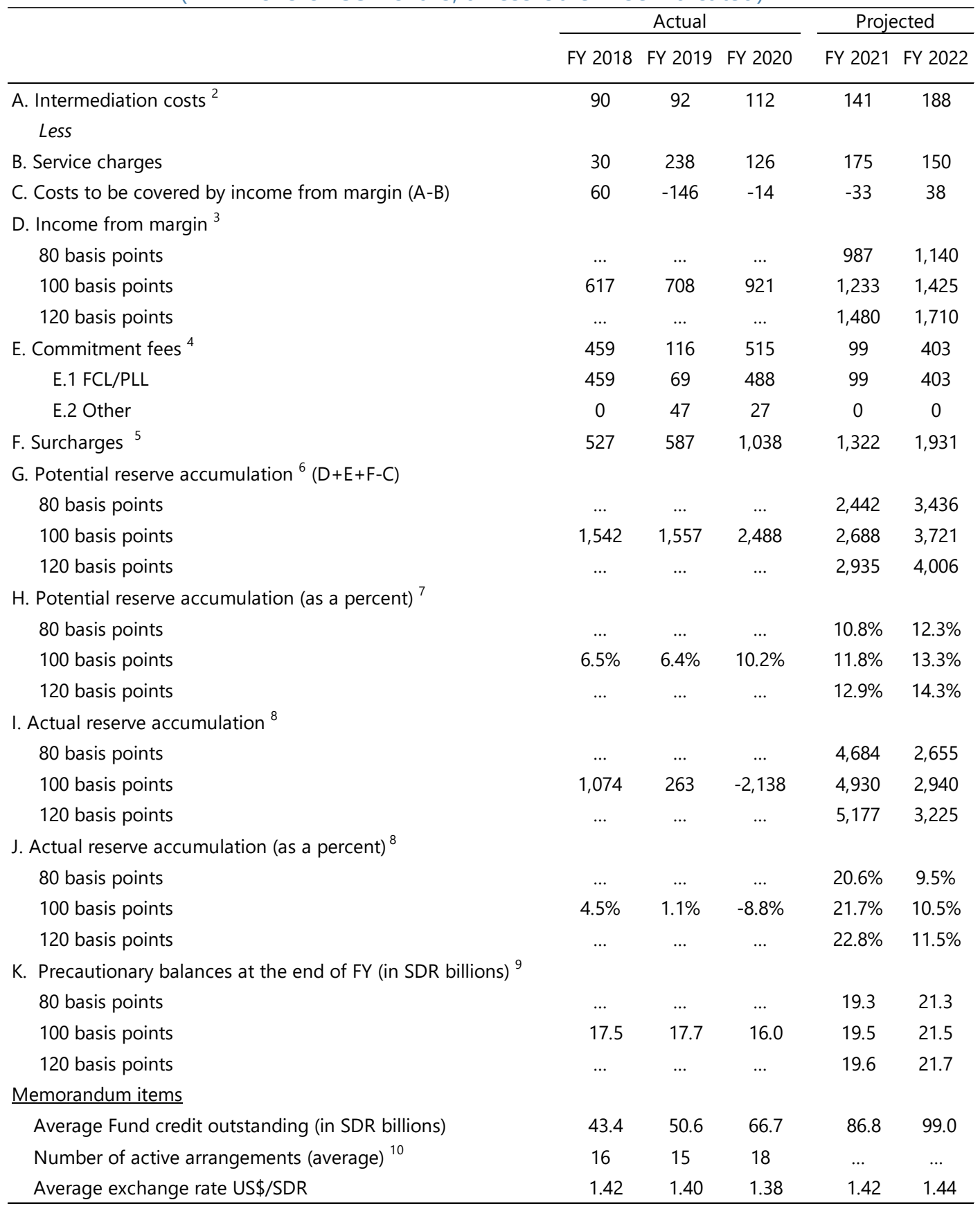

Source: Finance Department and Office of Budget and Planning

${ }^{1}$ For analytical purposes, surcharges and commitments fees are considered for reserve accumulation only.

${ }^{2}$ Costs related to the Fund's "generally available facilities".

${ }^{3}$ Derived by applying the margin against average Fund credit outstanding at the average US\$/SDR exchange rate.

${ }^{4}$ Includes commitment fees for expired or canceled arrangements.

${ }^{5}$ Surcharges are projected on the basis of current quotas and surcharge thresholds.

${ }^{6}$ Potential reserve accumulation is derived by assuming other sources of income are sufficient to cover non-intermediation costs.

${ }^{7}$ Potential reserve accumulation as a percent of precautionary balances at the beginning of the financial year.

${ }^{8}$ Additions to or reductions in reserves based on net income or loss for the year (including actual and projected IAS 19

gains/(losses) up to FY 2021 and excludes retained Endowment Subaccount investment income).

${ }^{9}$ Precautionary balances include the Fund's reserves and SCA-1 balance less the gold endowment of SDR 4.4 billion.

${ }^{10}$ Excludes FCL and PLL arrangements. 


\section{Reserve Accumulation}

30. Reserve accumulation is projected to remain relatively strong in FY 2022. Table 5 first illustrates the potential reserve accumulation that would result if lending income were required solely to cover intermediation costs and provide for additional reserves (Rows $G$ and $H$ ). In this hypothetical scenario, potential reserve accumulation with a margin of 100 basis points would rise to 13.3 percent in FY 2022. Projected actual reserve accumulation would be 10.5 percent of reserves in FY 2022 (Rows I and J). Precautionary balances are now projected to rise to SDR 21.5 billion by end-FY 2022, significantly higher than the SDR 19.4 billion estimated in April 2020. Table 5 further simulates reserve accumulation at alternative margins of 80 and 120 basis points, respectively.

\section{Updated projections of the pace of reserve accumulation are significantly higher than} those anticipated in April (Figure 3). ${ }^{38}$ Similar to the interim update, this reflects mainly a higher path for credit outstanding, under the desk survey of potential demand for Fund lending. ${ }^{39}$ Overall, income from the margin, surcharges, and service charges and the estimated pension-related (IAS 19) gain for FY 2021 are expected to increase the Fund's precautionary balances significantly compared to the previous projections, accelerating the pace of projected reserve accumulation over the medium term. The current projections are higher than the interim update and reflect mainly the large increase in the pension-related (IAS 19) gain. The indicative medium-term target, which was

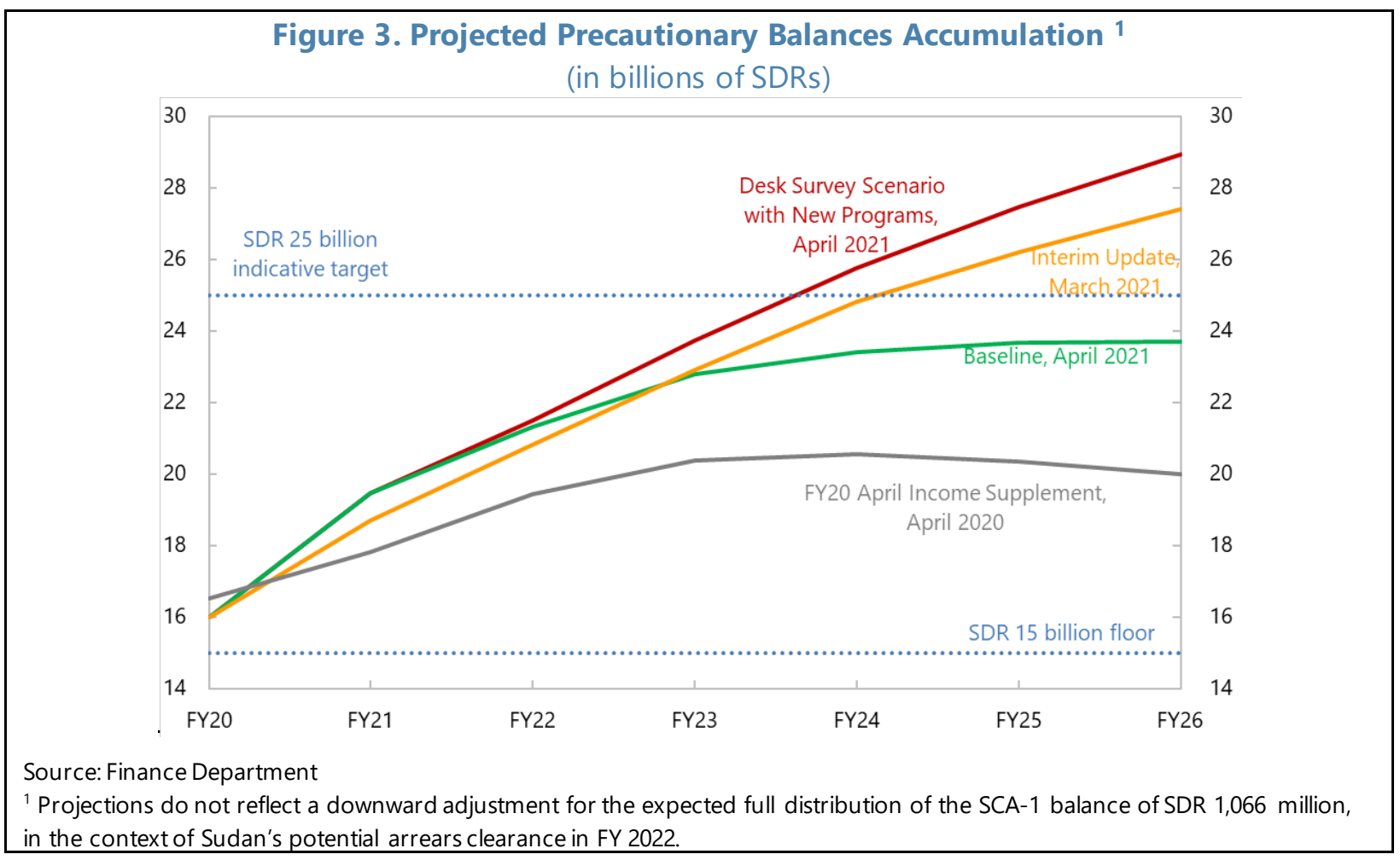

\footnotetext{
${ }^{38}$ Does not reflect the impact on precautionary balances of any distribution of the SCA-1 in the context of the ongoing discussions on Sudan's debt relief.

39 By contrast, the baseline projections in the April paper took account of arrangements approved through end-March 2020 and estimates of potential emergency loan demand (mainly in the form of Rapid Financing Instruments) associated with the COVID-19 pandemic.
} 
raised from SDR 20 billion to SDR 25 billion during the review of the adequacy of precautionary balances in October, is expected to be reached in FY 2024, about one year earlier than was projected in the interim paper.

\section{Alignment of Fund Borrowing Costs with Market Conditions}

\section{Rule I-6(4) requires a cross-check of the margin's alignment with long-term credit} market conditions. ${ }^{40}$ This aims to ensure that the cost of borrowing from the Fund is not too high or low relative to the cost of long-term market funding. Staff benchmarks based on EMBI spreads provide a useful guide for this purpose, but should not be applied mechanistically without judgement on the global financial context and future developments. ${ }^{41} \mathrm{As}$ in the past, the level of the margin is compared to the lowest quartile of EMBI spreads (reflecting the spreads for the more creditworthy borrowers within the sample) as a proxy measure to account for the lower credit risk the Fund faces as a cooperative public policy institution. ${ }^{42}$ Market borrowing spreads reflect a country-specific, time-varying credit risk premium. While the Fund also bears credit risk when it lends to member countries, it uses a multilayered framework-including policies on access, program design, and conditionality to support members' BoP adjustment, and its de facto preferred creditor status, among other elements—-to mitigate such credit risk.

\section{The cost of Fund credit at the current margin remains broadly in line with the staff} benchmarks for long-term credit market conditions. Since the last review in April 2020, the EMBI spreads have slightly declined. The five-year rolling average of the spreads remains broadly unchanged since the last review (Figure 4). The median for the lowest quartile EMBI spread stands at 47 basis points above the current margin (relative to 53 basis points at the time of the April 2020 income review, Table 6). Staff therefore does not see any fundamental change in the alignment of the margin with long-term credit market conditions.

\footnotetext{
40 See A New Rule for Setting the Margin for the Basic Rate of Charge (11/22/11).

41 The index for EMBI spreads does not include advanced economies that currently have outstanding credit from the Fund. However, their share of overall outstanding credit has fallen to less than 5 percent as of end-January 2021. Moreover, based on currently available measures, staff continues to view the EMBI-based measure as the most appropriate metric of long-term market conditions. See Annex II, Review of the Fund's Income Position for FY 2014 and FY 2015-2016 (4/7/2014).

42 In the past, staff has also adjusted spreads to account for the maturity difference between the SDR interest rate (based on a floating rate composed of three-month instruments) and the EMBI measures (based on medium-term fixed interest rate instruments). As this estimation has been subject to a few conceptual and data limitations, and the resulting adjustments have been marginal (in the magnitude of ten basis points), the assessment of the margin in this review is based solely on credit-risk adjusted EMBI spreads.
} 
Figure 4. EMBIG Spreads: Total Composite and Bottom Quartile

(in basis points) ${ }^{1}$

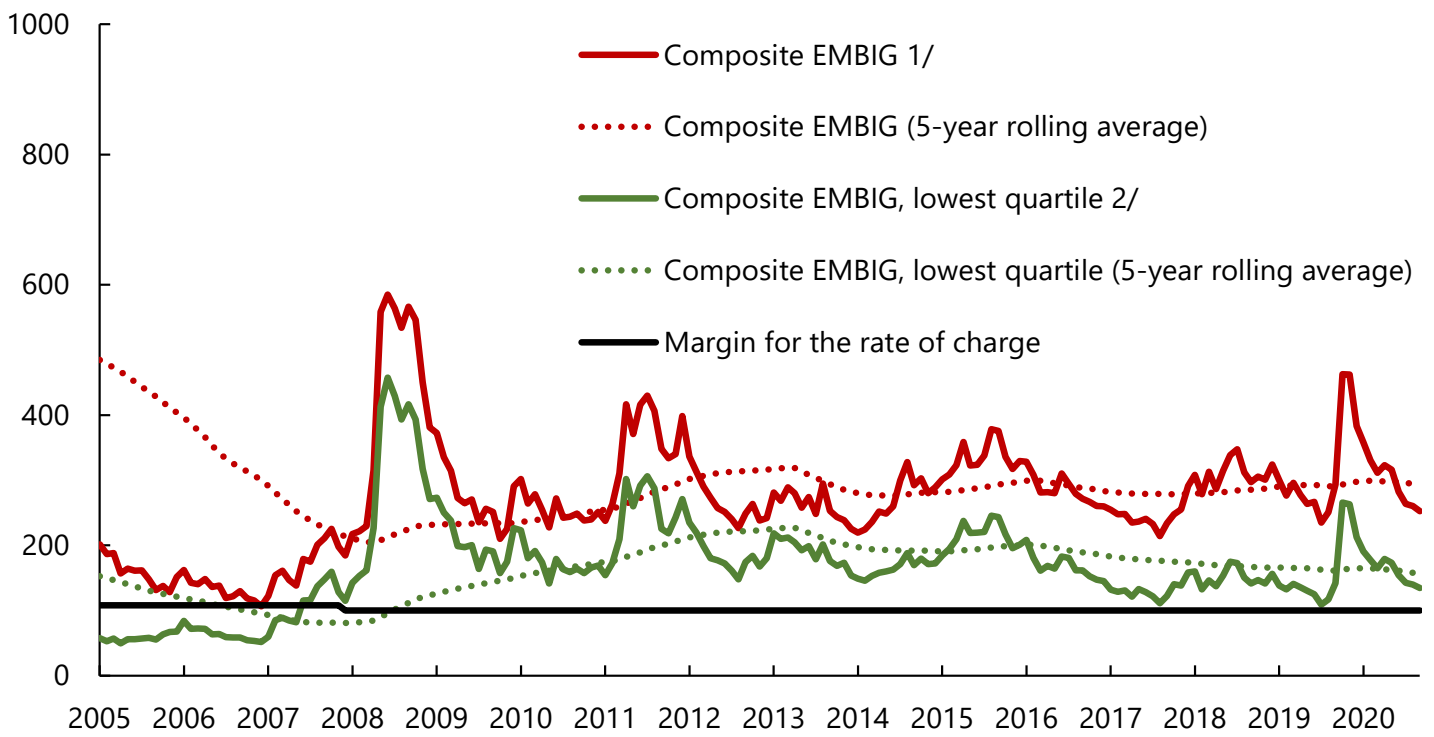

Source: JPMorgan and Fund staff calculations.

${ }^{1}$ Weighted average of spreads from the JPMorgan Emerging Market Bond Index Global Sovereign Spread (US dollar) and the JPMorgan Euro EMBI Global Government Spread, using US dollar and euro weights in the SDR basket.

${ }^{2}$ Weighted average of the lowest quartile of country-specific US dollar EMBI spreads and the lowest quartile of country-specific euro EMBI spreads, using US dollar and euro weights in the SDR basket.

Table 6. Long-Term Credit Market and Comparator Spreads ${ }^{1}$

(median spread unless otherwise noted, in SDR-equivalent basis points)

\begin{tabular}{|c|c|c|c|}
\hline & $2006-2010$ & $2011-2015$ & $\begin{array}{c}\text { Mar } 2016 \text { - } \\
\text { Feb } 2021\end{array}$ \\
\hline \multicolumn{4}{|l|}{ Composite EMBI Global 1/ } \\
\hline 5-year average & 245 & 289 & 292 \\
\hline 5-year median & 219 & 277 & 284 \\
\hline \multicolumn{4}{|l|}{ Composite EMBI Global, Lowest Quartile 2/ } \\
\hline 5-year average & 165 & 195 & 156 \\
\hline 5-year median & 151 & 180 & 147 \\
\hline \multicolumn{4}{|l|}{ Memorandum items } \\
\hline Past borrowers (5-year median) 3/ & 229 & 293 & 262 \\
\hline Margin for the rate of charge (5-year average) & 104 & 100 & 100 \\
\hline
\end{tabular}

Sources: Bloomberg, JP Morgan, and Fund staff calculations.

${ }^{1}$ Weighted average of spreads from the JPMorgan Emerging Market Bond Index Global Sovereign Spread (US dollar) and the JPMorgan Euro EMBI Global Government Spread, using US dollar and euro weights in the SDR basket.

${ }^{2}$ Weighted average of the lowest quartile of country-specific US dollar EMBI spreads and the lowest quartile of country-specific euro EMBI spreads, using US dollar and euro weights in the SDR basket.

${ }^{3}$ Weighted average of the median of country-specific US dollar EMBI spreads and the median of country-specific euro EMBI spreads, using US dollar and euro weights in the SDR basket, considering a sample of members with Fund GRA arrangements between 2000 and 2020 . 


\section{Exceptional Circumstances Clause}

\section{The Fund will need to continue to rely on its lending income to cover a portion of its}

non-lending operational costs. The Fund's non-lending operational income, consisting of investment income and implicit income from its interest free resources, is projected to cover on average about 49 percent of the Fund's projected non-lending operational expenses over the medium-term (Figure 5). This coverage ratio is expected to improve significantly toward the end of the projection period, although remaining highly sensitive to the higher lending income expected under the desk survey scenario and projected path of interest rates. The projected coverage ratio also assumes the commencement of payouts from the Endowment Subaccount in FY 2022. The need to cover the residual non-lending expenses by income from the margin reduces its expected contribution to the Fund's reserve accumulation.

Figure 5. Projected Non-Lending Operational Income and Non-Lending Expenses ${ }^{1}$ (in millions of SDR, percent)

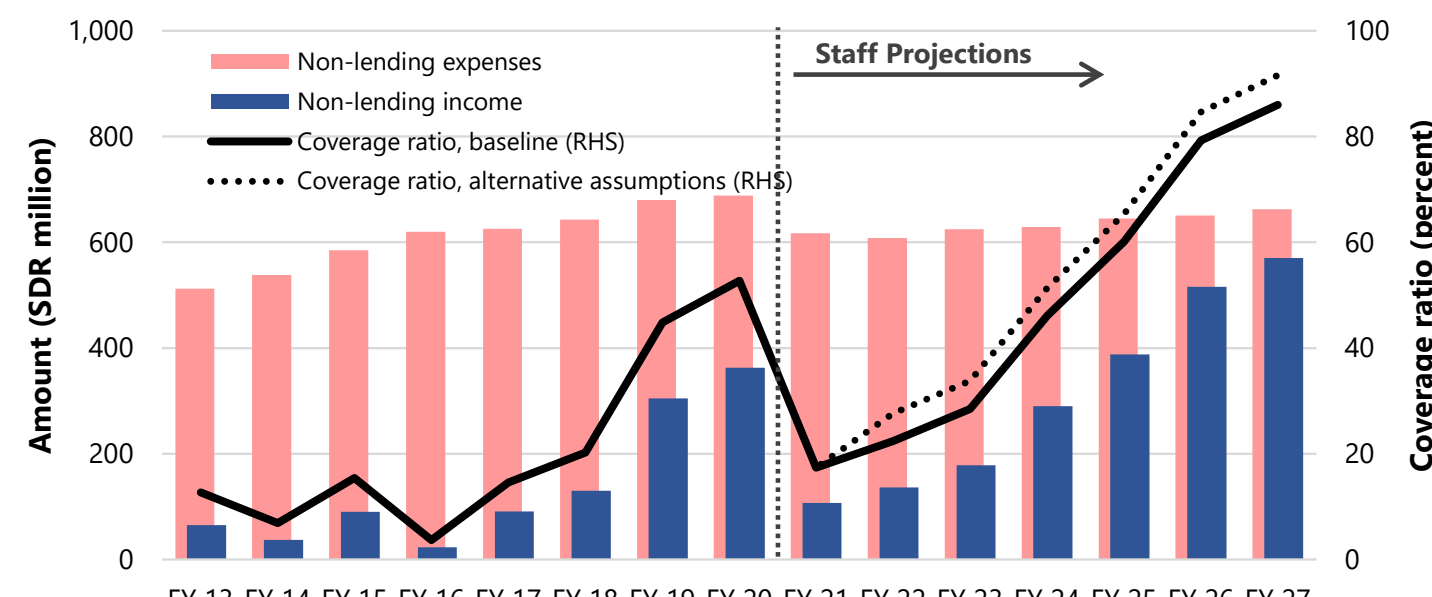

FY 13 FY 14 FY 15 FY 16 FY 17 FY 18 FY 19 FY 20 FY 21 FY 22 FY 23 FY 24 FY 25 FY 26 FY 27

Source: Finance Department and Office of Budget and Planning

${ }^{1}$ Non-lending operational income comprises investment income and implicit income from interest free resources. Projections assume an initial 1 percent USD payout from the Endowment Subaccount commencing in FY 2022 (increasing by GED thereafter). Alternative projection assumes 1.5 percent initial payout. Non-lending expenses are net administrative expenditures less intermediation costs related to generally available facilities, PRGT and SDR Department.

\section{Burden sharing adjustments reflect the current levels of overdue obligations and} burden sharing amounts collected in previous quarters. The burden sharing decision allows for a "carry-forward" of excess amounts generated from a minimum adjustment to the rate of charge and the rate of remuneration. ${ }^{43}$ If the amounts brought forward are sufficient to offset deferred charges in subsequent quarter(s), no adjustments are necessary for such quarters (see Table 7). This was the case for the first three quarters of FY 2021. The projected burden sharing rates in Q4 FY 2021 stand at zero basis points as well for both debtors and creditors. With the settlement of Somalia's arrears to the Fund in the fourth quarter of FY 2020, overdue GRA charges owed by Sudan were the only charges subject to burden sharing during FY 2021. For a report on the cumulative burden sharing adjustments (by member) at end-January 2021 refer to www.imf.org/external/np/fin/tad/query.aspx.

${ }^{43}$ See The Fund's Income Position for FY 2010-Midyear Review (12/08/09), paragraphs 8-10. 
Table 7. Recent Burden Sharing Adjustment Rates

(in basis points, unless otherwise stated)

\begin{tabular}{|c|c|c|c|c|c|c|c|c|}
\hline & FY14 & $\mathrm{FY} 15^{3}$ & FY16 & FY17 & FY18 & FY19 & FY20 & FY21 \\
\hline & & & & & & & & Projected \\
\hline \multicolumn{9}{|l|}{ Rate of Remuneration ${ }^{1}$} \\
\hline Deferred charges & $-{ }^{2}$ & 0.300 & 0.575 & 0.375 & 0.500 & 0.500 & 0.225 & 0.000 \\
\hline \multicolumn{9}{|l|}{ Rate of Charge ${ }^{1}$} \\
\hline Deferred charges & $-{ }^{2}$ & - & - & 0.150 & 0.500 & 0.500 & 0.275 & 0.000 \\
\hline Average SDR interest rate (in percent) & 0.093 & 0.061 & 0.051 & 0.187 & 0.678 & 1.037 & 0.763 & 0.077 \\
\hline Average basic rate of charge (in percent) & 1.093 & 1.061 & 1.051 & 1.187 & 1.678 & 2.037 & 1.763 & 1.077 \\
\hline
\end{tabular}

Source: Finance Department.

${ }^{1}$ The average rates have been calculated using the quarterly burden sharing rates and SDR interest rates. No adjustments to the rate of charge in FY 2015, FY 2016, and the first two quarters in FY 2017.

${ }^{2}$ Annual average rate calculated is less than 0.5 basis points. (prior to October 2014, the minimum burden sharing adjustment rate was set at 1 basis point).

${ }^{3}$ In October 2014, the minimum for the quarterly burden sharing rate adjustment of 1 basis point was reduced to 0.1 basis point. 


\section{Proposed Decisions}

\section{Decisions Pertaining to FY 2021}

- Decision 1 provides for the assessment on SDR Department participants for the reimbursement of the General Department for the expenses of conducting the business of the SDR Department in FY 2021.

- Decision 2 provides for the suspension of reimbursement to the GRA for PRGT administrative expenses for FY 2021.

- Decision 3 provides for the transfer of income from the Fixed-Income Subaccount of the Investment Account to the GRA for use in meeting FY 2021 administrative expenses. The income of the Endowment Subaccount for FY 2021, if any, shall be retained.

- Decision 4 provides for the placement of FY 2021 GRA net income to the Fund's Special Reserve and the General Reserve. Specifically, the net income amount of the GRA up to the amount of the GRA's net loss in FY 2020 will be placed in the Fund's Special Reserve, and any additional net income amount will be placed in equal parts to the Fund's Special Reserve and General Reserve.

- Decision 5 provides for the transfer of currencies from the GRA to the Investment Account equivalent to the increase of the special and general reserves following the placement of FY 2021 net income.

\section{Decisions Pertaining to FY 2022}

- Decision 6 completes the review of the Fund's income position and concludes that there are no fundamental changes that warrant adjustment to the current rate of charge at 100 basis points over the SDR interest rate for FY 2022.

Decisions 1 to 4 and Decision 6 each may be adopted by a majority of the votes cast. Decision 5 may be adopted by a 70 percent majority of the total voting power.

\section{Decision 1. Assessment under Article XX, Section 4 for FY 2021}

Pursuant to Article XVI, Section 2 and Article XX, Section 4 of the Articles of Agreement and Rule T-2 of the Fund's Rules and Regulations, it is decided that:

(i) The General Department shall be reimbursed for the expenses of conducting the business of the SDR Department for the period of May 1, 2020 through April 30, 2021; and

(ii) An assessment shall be levied on all participants in the SDR Department. The special drawing right holdings accounts of participants shall be debited on April 30, 2021 with an amount equal to 0.00167905 percent of their net cumulative allocations of special drawing rights. The total assessment shall be paid into the General Department. 


\section{Decision 2. PRG Trust Reimbursement for FY 2021}

Notwithstanding paragraph 3 of Decision No. 8760-(87/176), adopted on December 18, 1987, for the 2021 financial year, no reimbursement shall be made to the General Resources Account from the Reserve Account of the Poverty Reduction and Growth Trust ("PRGT") for the cost of administering the PRGT.

\section{Decision 3. Transfer of Investment Income for FY 2021 to General Resources Account}

The income of the Fixed-Income Subaccount of the Investment Account for FY 2021 shall be transferred to the General Resources Account for use in meeting the expenses of conducting the business of the Fund during FY 2021. The income of the Endowment Subaccount for FY 2021 shall be retained in the Endowment Subaccount and invested according to the Rules and Regulations for the Investment Account.

\section{Decision 4. Placement of FY 2021 Net Income of the General Resources Account to the Special}

\section{Reserve and General Reserve}

The net income of the General Resources Account for FY 2021 shall be placed to the Fund's Special Reserve, provided that if net income in FY 2021 exceeds the amount of the net loss in FY 2020, an amount equivalent to this excess shall be placed in equal parts to the Fund's Special Reserve and General Reserve.

\section{Decision 5. Transfer of Currencies to the Investment Account for FY 2021}

Pursuant to Article XII, Section 6(f)(ii) of the Articles of Agreement, the Fund shall transfer from the General Resources Account to the Investment Account currencies in an amount equivalent to the difference between the Fund's general and special reserves as of April 30, 2021 and the cumulative 
amount of previous transfers of currencies from the General Resources Account to the Investment Account. This transfer of currencies to the Investment Account shall be effected in the context of the Financial Transactions Plan covering the period May-October 2021. The currencies transferred to the Investment Account pursuant to this decision shall be used for immediate investment in the Fixed-Income Subaccount in accordance with the Rules and Regulations for the Investment Account.

\section{Decision 6. The Rate of Charge on the Use of Fund Resources for FY 2022}

Pursuant to Rule I-6(4)(a), the Fund has completed the review of the Fund's income position and concluded that for FY 2022 there are no fundamental changes to warrant any adjustment to the margin for the basic the rate of charge as determined by Decision No. 16774-(20/51), adopted April 27, 2020. 


\section{Annex I. Decisions in Effect Related to the FY 2021 Income Position ${ }^{1}$}

\section{Decisions in Effect}

The Executive Board has taken the following decisions affecting the Fund's income position for FY 2021:

Rate of Charge

The margin for calculating the basic rate of charge in FY 2021 was set in 2020 at 100 basis points for a period of two years (FY 2021-22). ${ }^{1}$ This decision was adopted under the exceptional circumstances clause of Rule I-6(4), which allows the margin for calculating the basic rate of charge to be set at a level other than that which is adequate to cover the estimated intermediation expenses of the Fund and to generate an amount of net income for placement to reserves.

\section{Burden Sharing for Deferred Charges ${ }^{2}$}

Income losses resulting from unpaid charges are shared equally between debtor and creditor members under the burden sharing mechanism largely pursuant to decisions taken in 2000 and 2009. Unless amended by the Board, this mechanism will continue for as long as overdue obligations to the Fund persist. ${ }^{3}$

\section{Special Charges ${ }^{4}$}

For overdue repurchases, the special rate of charge is set to equal the excess, if any, of the SDR interest rate over the basic rate of charge (Paragraph 3 of Decision No. 8165-(85/189), as amended). Pursuant to Rule I-6(4), the basic rate of charge "shall be determined at the beginning of each financial year as the SDR interest rate under Rule T-1 plus a margin expressed in basis points". Since under the current system for setting the basic rate of charge, that rate is always in excess of the SDR interest rate, members are not subject to special charges on their overdue repurchases.

In FY 2019 the Board reviewed the system of special charges and adopted a decision to amend Section VI of the 1985 decision on special charges, to shift the requirement for regular review from the annual review of the Fund's income position to the five-yearly Review of the Fund's Strategy on Overdue Financial Obligations. Accordingly, the next review of the special charges framework would be due by 2022 but could take place sooner if circumstances warrant.

${ }^{1}$ Decision No. 16774-(20/51), adopted on April 27, 2020.

2 Decision No. 12189-(00/45), adopted on April 28, 2000, as amended.

${ }^{3}$ See Recent Fall in the SDR Interest Rate-Implications and Proposed Amendments to Rule T-1 (10/16/14).

${ }^{4}$ The requirement for an annual review of special charges was amended. See Review of the Fund's Income Position for FY 2019 and FY 2020 (04/03/19).

\footnotetext{
${ }^{1}$ Review of the Fund's Income Position for FY 2020 and FY 2021-2022 (04/13/20).
} 


\section{Annex III. IAS 19 Accounting for Employee Benefits}

IAS 19 is the International Financial Reporting Standard (IFRS) that deals with accounting for pension and other employee benefits in the financial statements of the Employer (see Box A2.1). Reporting requirements under the standard introduce an additional source of volatility to Fund income as the full impact of remeasurement gains and losses incurred during the year is reflected in the annual pension-related (IAS 19) adjustment.

Figure A2.1 illustrates the Fund's remeasurement gains and losses for FY 2000-21 (restated retrospectively under amended IAS 19 for FY 2000-13). Historically, variances in the discount rate used to derive the net present value of pension obligations and movements in the fair value of pension assets have had the largest impact on changes in the funded status of the defined benefit pension plan. Any volatility in the underlying actuarial assumptions can translate into volatility in the Fund's reserves and income. As a result, on an annual basis, remeasurement gains and losses can be substantial; however, these tend to offset each other over time, as evidenced recently over the last few years.

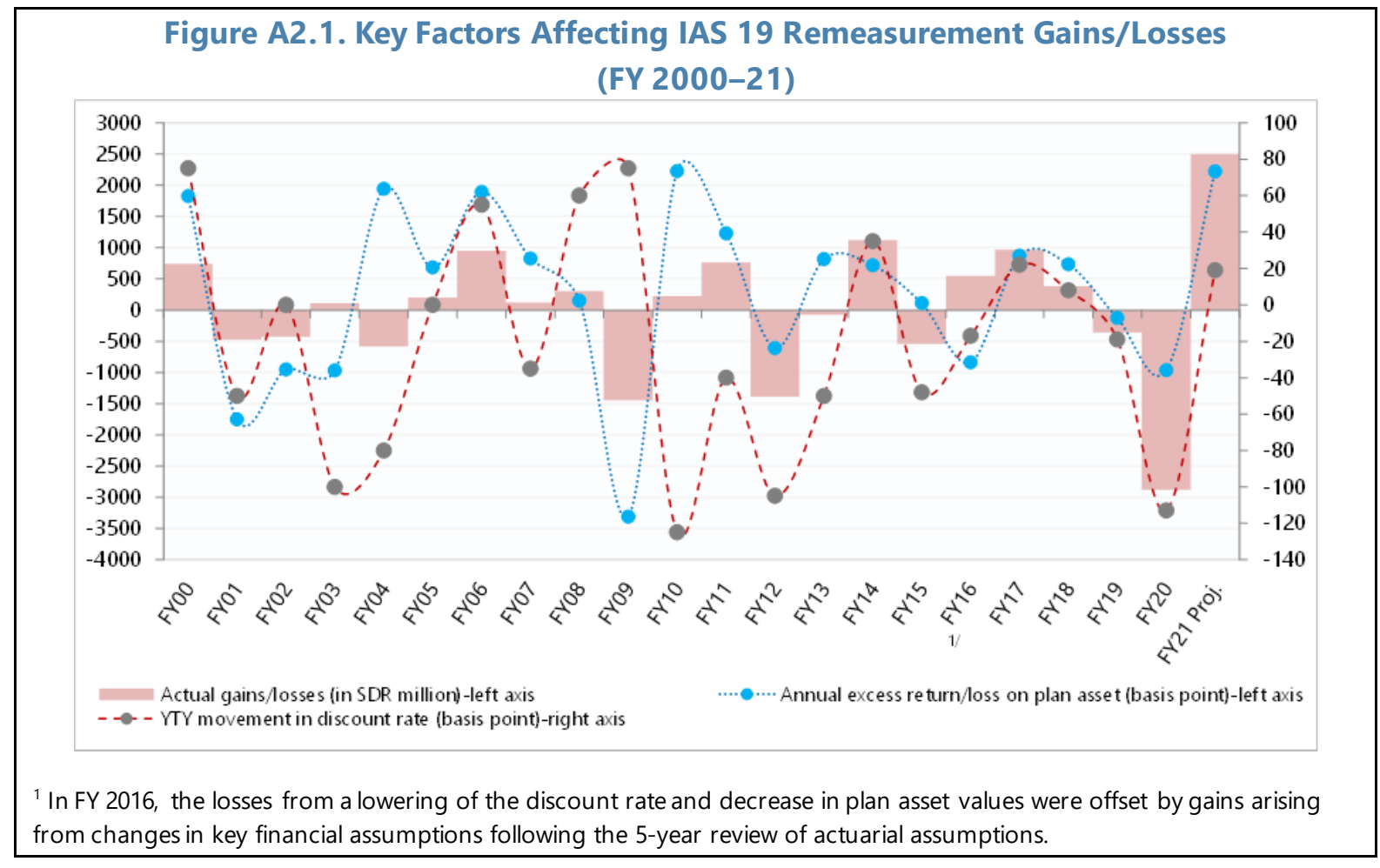

Going forward, pension-related gains and losses are expected to remain unpredictable and any volatility in the underlying actuarial assumptions would translate into volatility in the Fund's income and reserves. 


\section{Box A2.1. IAS 19-Background to the Standard and Accounting in the Fund}

Since the adoption of IFRS in FY 2000, the Fund has followed IAS 19 in accounting for employee benefits. The objective of IAS 19 is to ensure that the liability associated with services provided by employees in exchange for benefits to be paid in the future and the related annual expense is properly recognized by the employer in its financial statements. IAS 19 prescribes the accounting by employers for (i) short-term employee benefits (e.g., salaries and wages); and (ii) post-employment benefits (e.g., pension, post-retirement health benefits, and termination grants). The employer recognizes an expense for short-term employee benefits in the period in which an employee has rendered services. Cash outflows associated with long-term benefits are subject to a high degree of uncertainty and are actuarially determined.

To meet the benefit obligations associated with post-employment and long-term benefits, the Fund has sponsored a defined benefit plan (Staff Retirement Plan) and a separate Retired Staff Benefits Investment Account. The Fund reports on the balance sheet a net asset or liability equal to the difference between the fair value of plan assets and the net present value of the defined benefit obligation. To determine the present value of the defined benefit obligation, the Fund discounts projected future cash outflows by applying demographic assumptions (e.g., mortality and employee turnover), and financial assumptions (e.g., the discount rate, salary increases, inflation rate, and future medical costs). Changes in underlying assumptions from year to year give rise to actuarial gains or losses (e.g., a reduction in the discount rate, and all else being equal, would result in a higher defined benefit obligation that contributes to a remeasurement loss). ${ }^{1}$ The change in the net asset (or liability), after taking into account annual pension costs, the employer's contributions to the plans, and remeasurement gains and losses, determines the IAS 19 gain or loss for the year.

In FY 2014, IAS 19 was amended eliminating the "corridor method". As a result, all gains and losses arising from changes in actuarial assumptions are recognized in the year incurred. The amendment was implemented retrospectively such that a one-time adjustment for the cumulative unrealized actuarial losses was charged against the reserves on May 1, 2013 (start of the financial year), bringing the Fund's net asset (or liability) and reserves to the same level as if the Fund had never chosen to apply the "corridor method".

\section{Accounting vs. Funding}

The actuarial methods under IAS 19 to measure the IAS 19 expense in the Fund's financial statements are different from the actuarial method used to determine the Fund's annual contribution for the pension plans (i.e., the funding requirement). Therefore, the accounting for employee benefits differs between the Fund's financial statements (accrual basis) and the administrative budget (cash basis for employer's contributions). The resulting differences can be substantial but should net to zero over the life of the pension and benefit plans, as from an accounting perspective the net IAS 19 pension expenses necessarily equal the employer's funding over time.

${ }^{1}$ Under IAS 19, the discount rate is to be determined by reference to market yields at the end of the reporting period, on "high quality corporate bonds". 


\section{Annex III. EA Payout Policy Framework}

The EA payout policy framework (Box A3.1) was established to support the EA's long-term financial objectives and achieve a balance between providing a meaningful contribution to the Fund's income and preserving the real value of the EA over time. ${ }^{1}$ These high-level implementation parameters were endorsed by the Board in the April 2018 discussion of the Fund's income position. $^{2}$

Payout amounts are to be determined based on a constant real payout rule which is expected to result in relatively stable and predictable annual payouts in US dollar terms. To safeguard the EA corpus in adverse market conditions, additional parameters include: (i) aligning the initial value of the payout with the prevailing return outlook, and (ii) setting a maximum limit of the payout as a percentage of the EA's total net asset value (NAV) that would trigger suspension of future payouts.

\section{Box A3.1. EA Payout Policy Framework}

In April 2018, the Executive Board endorsed an EA payout policy framework with the following key features:

- Annual payout amounts in US dollars will be determined according to a constant real payout rule.

- Annual payouts will be decided at the time of the Fund's net income disposition decisions. The initial nominal US dollar value of the payout will be aligned with the prevailing return outlook.

- The deflator for annual inflation adjustments will be the Fund's annual GED.

- The payout will be subject to a NAV-based limit which would trigger a suspension of payouts. The initial value of the payout and NAV-based limit will be decided by the Board prior to the first payout.

- $\quad$ Payouts will be delayed for three years (until FY 2021) to build a cushion of retained investment income.

- The retained investment income would be reassessed at the end of the three-year period.

\footnotetext{
${ }^{1}$ In particular, recognizing the public good aspects of many Fund activities, efforts have been directed towards the development of a framework that relies on broader and more sustainable income sources, rather than continuing to rely primarily on income from the Fund's financial support to members to cover general administrative expenses.

${ }^{2}$ Review of the Fund's Income Position FY 2018 and FY 2019-2020 (04/05/18).
} 


\section{Annex IV. Endowment Payout-Practical Considerations}

The Board endorsed a set of criteria for determining a constant real payout rule, supplemented by safeguards to help protect real value of the EA (Box A3.1).

- Reassess adequacy of retained income cushion ("cushion") based on EA NAV. The target cushion could be sized so the portfolio could absorb one extreme event equivalent to a two-standard deviation market shock. Based on current projections, this is equivalent to around 17.4 percent. In practice the time required to achieve the required cushion would be uncertain and subject to market conditions. However, the Board could decide to delay payouts for a certain period with the intent of building an adequate income cushion in the EA. The EA cushion represents the difference between the EA's NAV and its corpus. The corpus is estimated based on principal amounts invested in the EA since inception, adjusted for the GED. ${ }^{1}$ These parameters are calculated monthly by the Fund's custodian.

- Review return outlook/projections for EA. The initial value of the payout would need to be aligned with a conservative estimate of the projected long-term EA real returns in US dollar terms. This estimate would ideally be associated with a relatively high level of confidence (or conversely a lower than average probability of underperformance). Based on estimates, a payout around 1 percent would meet the criteria. For purely illustrative purposes, this paper uses a payout of USD 89 million (equivalent to about SDR 62 million) or around 1 percent of NAV (similar to the example provided to the Board in March 2018).

- Current USD amount of initial payout. The constant real payout rule is used to determine future payout amounts after the initial payout is determined. Under this rule, the payout amount for any given year would be calculated as the prior year's USD payout increased by the deflator (GED). If the payout amount as a percentage of NAV exceeds the maximum limit specified above, it will be suspended.

- Maximum limit of payout to trigger future suspension of the payout. Based on the level of the EA's cushion, a maximum limit would be set as a percentage of NAV to trigger suspension of future payouts. An adequate cushion is a prerequisite for commencing payouts and to prevent a start-stop scenario. For example, given the limited size of the cushion (18.5 percent as of February 2021), the implied maximum limit will be very close to the initial payout value and may be reached relatively quickly. For example, a 1 percent initial value of the payout and cushion size of 18.5 percent would imply a maximum limit of approximately 1.2 percent. In other words, if in future years the payout amount reaches 1.2 percent of the current EA NAV, a suspension of payouts would be triggered. Following a suspension, staff will need to repeat the reassessment of the EA cushion as described above and calculate a new maximum limit, before proposing to recommence payouts.

\footnotetext{
${ }^{1}$ Starting in FY 21, the global external deflator is the U.S. CPI projection as published in the most recent WEO which is the January WEO Update.
} 


\section{Annex V. Assumptions Underlying the Income Projections}

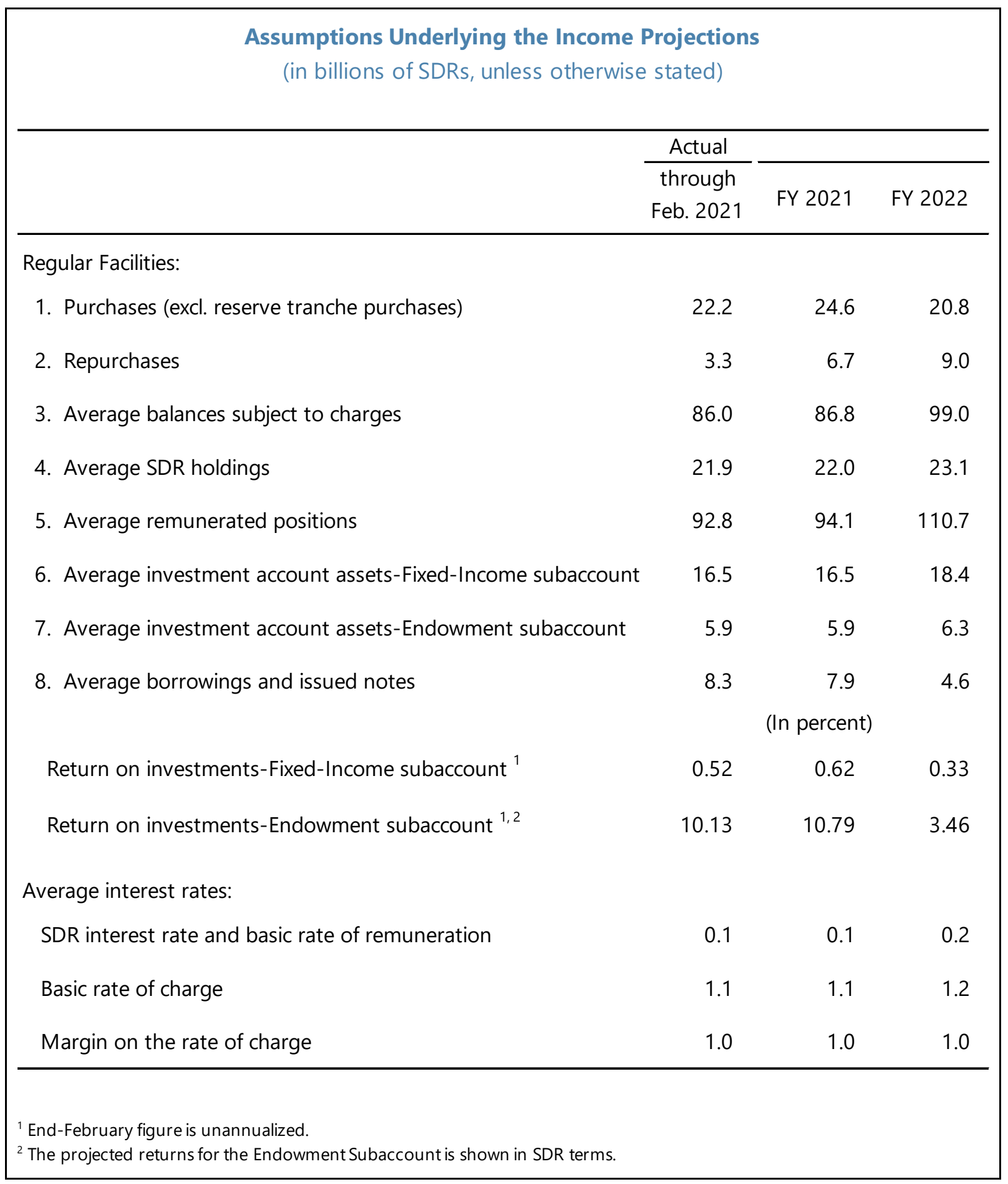




\section{Annex VI. Consolidated Medium-Term Income and Expenses}

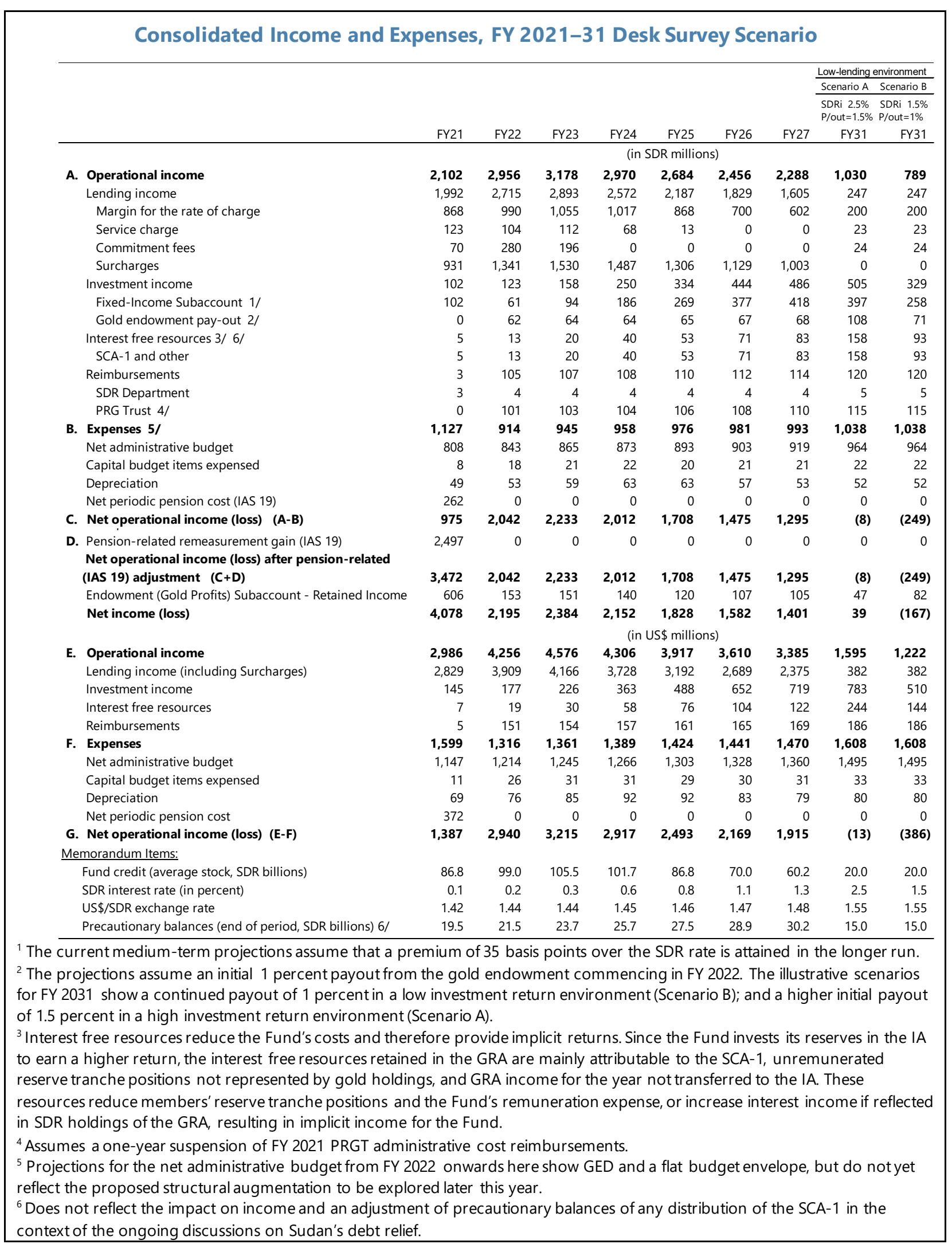




\section{Annex VII. Reconciliation of Projected Income and Expenses- FY 2021}

\section{Linking the Analytical Presentation with the Fund's Income Statement}

The purpose of this Annex is to prepare a reconciliation between the analytical framework presented in Table A7.1 of this paper and the traditional format used to prepare the Fund's income statement under IFRS. ${ }^{1}$ The formulation of the Fund's income and expense flow results in the same projected net income position. However, the analytical framework is preferred in discussing the income position as it succinctly captures the main variables that drive the Fund's income position. To this end, the presentation focuses on the net contribution made by the Fund's income-earning assets. The starting point to move from the traditional format in the Fund's financial statements to the analytical framework in the paper is to net the financing costs (remuneration and interest on borrowings) against the income generated from Fund credit and the GRA's SDR holdings. This provides the income from the margin and interest free resources by eliminating the flows from the SDR interest rate between the debtor and creditor members of the Fund. Thereafter, the main adjustments involve re-arranging the various line items on the Fund's IFRS financial statements to the analytical framework. This includes:

- Reallocation of income from the Endowment Subaccount from total investment income since this amount is retained in the investment account; and

- Separation of the reimbursements from administrative expenses.

Table A7.1 below highlights this reconciliation process.

\footnotetext{
${ }^{1}$ The Annex is prepared in response to requests to simplify and explain the process of reconciling various aspects of the Fund's financial structure.
} 
Table A7.1. Reconciliation of the Accounting and Analytical Presentations of Projected Income and Expense-FY 2021

\begin{tabular}{|c|c|c|c|c|c|c|}
\hline & \multirow{2}{*}{$\begin{array}{c}\text { Actual } \\
\text { through } \\
\text { Feb. } 2021\end{array}$} & \multirow{2}{*}{$\begin{array}{c}\text { FY2021 } \\
\text { Current } \\
\text { Projection }\end{array}$} & \multicolumn{3}{|c|}{ Adjustments } & \multirow[b]{2}{*}{$\begin{array}{c}\text { Analytical } \\
\text { presentation }\end{array}$} \\
\hline & & & $\begin{array}{l}\text { Financing } \\
\text { costs }\end{array}$ & Expenses & $\begin{array}{l}\text { Endowment } \\
\text { income }\end{array}$ & \\
\hline \multicolumn{7}{|l|}{ A. Operational income } \\
\hline Interest and charges & 773 & 935 & -67 & & & 868 \\
\hline Surcharges & 764 & 931 & & & & 931 \\
\hline Interest on SDR holdings & 15 & 17 & $-17 \mathrm{i}$ & & & 0 \\
\hline Net income from investments & 654 & 708 & & & -606 & 102 \\
\hline Service charges and commitment fees & 181 & 193 & & & & 193 \\
\hline Total income & 2,387 & 2,784 & & & & \\
\hline \multicolumn{7}{|l|}{ B. Operational expenses } \\
\hline Remuneration ${ }^{1}$ & 63 & 73 & -78 & & & -5 \\
\hline Interest expense on borrowings & 6 & 6 & -6 & & & 0 \\
\hline Administrative expenses ${ }^{2}$ & 906 & 1,124 & & 3 & & 1,127 \\
\hline Total expenses & 975 & 1,203 & & & & \\
\hline \multicolumn{7}{|l|}{ Remeasurement of net assets/liabilities under retirement } \\
\hline benefits plans & & 2,497 & & & & 2,497 \\
\hline C. Net operational income after IAS 19 adjustment & & 4,078 & & & & \\
\hline \multicolumn{7}{|l|}{ Other reconciling items: } \\
\hline Reimbursements & & & & 3 & & 3 \\
\hline Endowment Subaccount investment income & & & & & 606 & 606 \\
\hline Net income ${ }^{3}$ & 1,412 & 4,078 & & & & 4,078 \\
\hline
\end{tabular}

${ }^{1}$ Interest free resources lower the Fund's costs by reducing members' reserve tranche positions and the Fund's remuneration expense or increase interest income if reflected in SDR holdings of the GRA, resulting in implicit income for the Fund. At the present time, the interest free resources retained in the GRA comprises the SCA-1, unremunerated reserve tranche positions not represented by gold holdings, and GRA income for the year not transferred to the IA.

${ }^{2}$ Administrative expenses presented on an IFRS basis include net administrative expenditures, capital budget items expensed, depreciation and net periodic interest costs. This is partially offset by reimbursements to the GRA. Pension related (IAS 19) remeasurement gains/(losses) at end-February 2021 are excluded.

${ }^{3}$ Income statement on the basis presented in the Fund's annual IFRS financial statements. 